\title{
Slovakia: Between Euro-Optimism and Euro-Concerns
}

\author{
Zuzana Vikarská and Michal Bobek
}

\begin{abstract}
In the Slovak constitutional system, the understanding of the concept of the rule of law is closer to the German concept of the Rechtsstaat rather than the common law concept. The constitutional elements of the Slovak accession to the EU have been largely settled by a comprehensive and detailed EU Amendment to the Constitution (2001). The accession to the EU was confirmed by a referendum in 2003. Constitutional amendments regarding EU and international law include provisions that enable the implementation of EU law by governmental regulations. The report generally observes a lack of case law and scholarly debate on matters relating to Slovakia's membership in the EU. Some critical voices have considered the Slovak solutions regarding the European Arrest Warrant to be overly enthusiastic and lacking the constitutional guarantees provided elsewhere. However, a constitutional challenge was brought with regard to the Data Retention Directive, together with a request by the claimants to refer a question to the ECJ. The Constitutional Court decided to wait for the ECJ judgment in Digital Rights Ireland and subsequently declared that the implementation measures were in breach of
\end{abstract}

Zuzana Vikarská is Lecturer in Constitutional Law at Masaryk University in Brno, Czech Republic, and DPhil candidate at the University of Oxford. e-mail: zuzana.vikarska@law.ox.ac.uk. Michal Bobek is Professor of European Law, College of Europe, Bruges, and Research Fellow, Institute of European and Comparative Law, University of Oxford. e-mail: michal.bobek@eui.eu. All websites accessed 5 October 2015. Text submitted 7 January 2015.

\footnotetext{
Z. Vikarská (凹)

Masaryk University, Brno, Czech Republic

e-mail: zuzana.vikarska@law.ox.ac.uk

Z. Vikarská

University of Oxford, Oxford, UK

M. Bobek

College of Europe, Bruges, Belgium

e-mail: michal.bobek@eui.eu
}

M. Bobek

Institute of European and Comparative Law, University of Oxford, Oxford, UK

(C) The Author(s) 2019

A. Albi and S. Bardutzky (eds.), National Constitutions in European

and Global Governance: Democracy, Rights, the Rule of Law,

https://doi.org/10.1007/978-94-6265-273-6_18 
several provisions of the Slovak Constitution, without addressing the alleged breach of the Charter provisions. The report generally recalls the high value placed on the right to privacy in Central and Eastern Europe, given the historical reality of surveillance by the secret police before 1989. Debate on the ESM Treaty was held at the political level; the report surmises that constitutional challenges might arise if citizens were actually asked to pay. More broadly, the report observes that the ongoing interaction between the national and European legal orders need not be one-directional, requiring only changes in the national legal systems; rather, a cluster of Member States might push towards a constitutional change at the European level.

Keywords The Slovak Constitution - Constitutional amendments regarding EU and international co-operation - The Slovak Constitutional Court

Constitutional review - Fundamental rights and the Rechtsstaat approach to the rule of law - Data Retention Directive, surveillance and the right to privacy and secrecy of communications - European Arrest Warrant • Publication of laws

Absence of constitutional limits - Referendum - Kyrian and the right to judicial review in EU mutual recognition system in administrative co-operation

ESM Treaty - The right to property

\section{Introductory Note to the Slovak Report}

The Slovak Republic (Slovakia) is a smaller jurisdiction. In July 2014, its estimated population was slightly under five and half million inhabitants. ${ }^{1}$ Being a smaller EU jurisdiction has two consequences for the purpose of this report. First, in smaller jurisdictions, not that many cases are likely to be litigated. Thus, a number of issues raised by this questionnaire have not yet been addressed judicially in Slovakia. Secondly, in contrast to larger states, there is relatively little legal scholarship being produced on the specific and specialised matters addressed in this questionnaire. For these two reasons, together with the fact that the constitutional elements of the Slovak accession to the EU have been largely settled by a comprehensive and detailed EU Amendment to the Slovak Constitution, with regard to a number of specific questions asked, the authors of this report can provide but an advised estimate on how the issue would likely be tackled if it were to arise in the future, but hardly a reflection of any established national case law or comprehensive scholarly debates.

\footnotetext{
${ }^{1}$ The CIA World Fact book gives the estimate of 5,443,583 inhabitants. https://www.cia.gov/ library/publications/the-world-factbook/geos/lo.html.
} 


\section{Constitutional Amendments Regarding EU Membership}

\subsection{Constitutional Culture}

1.1.1 According to the division suggested by Besselink, ${ }^{2}$ the Constitution of the Slovak Republic ${ }^{3}$ (hereinafter Constitution or Slovak Constitution) could be said to fall within the first category of constitutions, i.e. those with 'a legal character, with detailed rules and enforceability in courts'. The Constitution is rather detailed, consisting of 156 articles, with most articles further subdivided into a number of detailed paragraphs. Furthermore, the Constitution also includes a full catalogue of fundamental rights (Chap. II, Arts. 12-54 of the Constitution).

The Constitution currently in force in the Slovak Republic was adopted in a specific historical and political context, when, as of 1 January 1993, the Czech and Slovak Federal Republic split into two sovereign countries. ${ }^{5}$ The draft of the Slovak Constitution played a strong symbolic role in the Slovak emancipation from the Federation, which had begun already earlier, in the course of 1992. Although the dissolution of the Federation on the international plane was the result of bilateral political arrangements put in place by the Czech and Slovak prime ministers, from the internal legal point of view the split of the Czech and Slovak Federation was the result of a unilateral secession of Slovakia carried out already in summer 1992. On 17 July 1992, the Slovak National Council (i.e. the Parliament of the Slovak part of the Federation, which was, however, not part of the Federal Parliament) adopted the Declaration on the Sovereignty of the Slovak Republic, a document invoking the natural right of states to self-determination and declaring the independence of the Slovak Republic. This declaration served as a stepping-stone to the ulterior adoption of the Constitution of the Slovak Republic, adopted on 1 September 1992 by a constitutional majority, ${ }^{6}$ again in the Slovak National Council. This Constitution did not merely regulate the constitutional arrangements in the Slovak part of the Federation, as foreseen by the federal legislation in force. ${ }^{7}$ Rather, it had the ambition to serve as a constitution of a sovereign state, the Slovak Republic, which, however, at that time was legally speaking a part of a Federation. From this point of view, the dissolution of the Federation became inevitable. The Slovak Constitution

\footnotetext{
${ }^{2}$ See Besselink 2006, pp. 113 et seq.

${ }^{3}$ Constitutional Act No. 460/1992 Coll., Constitution of the Slovak Republic. One of the English translations of the Slovak Constitution can be found at https:/www.prezident.sk/upload-files/ 46422.pdf. In some cases, the authors have slightly changed the wording of the translated provisions in order to express the content of the norm as precisely as possible.

${ }^{4}$ See the Questionnaire for this project.

${ }^{5}$ Generally on this process in English, see e.g. Stein 1997.

${ }^{6}$ The constitutional majority required was three-fifths of all the MPs, i.e. 90 out of 150 . Out of the 134 MPs present, 114 voted in favour of the Constitution, 16 voted against and 4 refrained from voting. For a stenographic record of the voting (in Slovak only), see http://www.nrsr.sk/dl/ Browser/Document?documentId=71565.

${ }^{7}$ Article 142(2) of Constitutional Act No. 143/1968 Coll., on the Czechoslovak Federation.
} 
entered into force on 1 October 1992 (with the exception of some provisions that entered into force on 1 January 1993), and the Czech and Slovak Federal Republic was formally dissolved on 1 January 1993.

The interpretation of the summer 1992 constitutional events and the de facto unilateral secession of Slovakia from the Federation are still far from settled. Also, it is not surprising that their interpretation is very different in the Czech Republic and in Slovakia. Be that as it may, although these circumstances probably did not amount to a cataclysmic event, the fact remains that the current Slovak Constitution 'was prepared in a hasty and secretive manner and gave rise to bitter political divisions in the Parliament'.

Lastly, as far as the constitutional tradition and influence are concerned, the Slovak Constitution can be said to be based on the Czechoslovak constitutional tradition, i.e. the constitutional norms and culture that the common state shared from 1918 until 1993, including several joint constitutions (of 1920, 1948 and 1960, respectively, as well as the federalisation legislation of 1969-1970, by which the formerly unitary Czechoslovakia was transformed into a federal state). In contrast to the Czech approach, however, the Slovak texts and constitutional culture appear to avoid explicit references to the Czechoslovak tradition. ${ }^{9}$

Apart from the common Czechoslovak origins, the Slovak constitutional culture finds on-going inspiration in the current Czech constitutional culture: the use of and references to Czech constitutional law textbooks and commentaries are common practice, whether openly acknowledged or somewhat hidden. It would appear that some limited inspiration comes also from Hungarian legal sources and constitutional case law, but this inspiration is even less likely to be openly acknowledged, often for political reasons. ${ }^{10}$

1.1.2 The Slovak Constitution is the foundation of the Slovak legal system, a document at the top of the hierarchy of legal acts. Its role and rationale are comparable to those of the constitutions of most other European states: to govern the main institutional setting of the state (including the separation of powers and due checks and balances) and to provide for a catalogue of the fundamental rights of its citizens. It is difficult, if not impossible, to single out any of the rationales as being key or dominant.

In Art. 1(1), the Constitution establishes the rule of law and the sovereignty of the Slovak Republic (SR), stating that 'the Slovak Republic is a sovereign, democratic state governed by the rule of law'. This sovereignty may be nonetheless

\footnotetext{
${ }^{8}$ Procházka 2002, p. 68.

${ }^{9}$ See, for example, the Preamble to the Slovak Constitution, which refers all the way back to the 'spiritual heritage of Cyril and Methodius and the historical legacy of Great Moravia' (Saints Cyril and Methodius were 9th century Byzantine Greek missionaries who preached among the Slavic tribes of Great Moravia and Pannonia, i.e. roughly the eastern part of the Czech Republic and western part of Slovakia today), but not to the Czechoslovak constitutional history of the 20th century.

${ }^{10}$ Further see Bobek 2013a, pp. 174-191.
} 
limited, as follows from Art. 1(2) (respect of international obligations) and Art. 7 (modalities of entry into international obligations).

Limits to state powers are mainly addressed in Art. 2(2), as well as in the institutional provisions further on, in which state powers are specifically fleshed out, while fundamental human rights are provided for in Arts. 12 to 54 (Chap. II: Basic Rights and Freedoms). The separation of powers as a principle is not explicitly mentioned in the Constitution, but the structure of the constitutional text clearly indicates that power is divided into legislative power (Chap. V), executive power (Chap. VI) and judicial power (Chap. VII).

\subsection{The Amendment of the Constitution in Relation to the European Union}

1.2.1 In the context of EU accession, the Slovak Constitution was significantly amended by Constitutional Act No. 90/2001 (the so-called 'EU Amendment', adopted on 23 February 2001, in force since 1 July 2001), adopted by 90 Members of Parliament (MPs) (the smallest number possible for a constitutional amendment), with 57 MPs voting against the proposal. This constitutional change paved the way towards accession to the EU, as well as to NATO.

The EU Amendment was a direct amendment of the Constitution. It inserted a number of key articles relevant for Slovak membership in the EU.

Article 1 was amended to include a second subparagraph that reads: 'The Slovak Republic recognizes and honours general rules of international law, international treaties by which it is bound and its other international obligations.'

Article 7, which in its original version only included what is now Art. 7(1), was further elaborated so as to differentiate among the various international organisations and international obligations to which Slovakia might be a party in the future. The amended Art 7 reads:

(1) The Slovak Republic may enter into a state union with other states upon its free decision. The decision on entering into a state union with other states, or on withdrawal from this union, shall be made by a constitutional law, which must be confirmed by a referendum.

(2) The Slovak Republic may, by an international treaty ratified and promulgated in a manner laid down by law, or on the basis of such treaty, transfer the exercise of a part of its rights to the European Communities and European Union. Legally binding acts of the European Communities and European Union shall have primacy over the laws of the Slovak Republic. The transposition of legally binding acts that require implementation shall be executed by law or a government ordinance pursuant to Art. 120, para. 2.

(3) The Slovak Republic may, with the aim of maintaining peace, security and democratic order, under the terms laid down by an international treaty, join an organization of mutual collective security. 
(4) In order for any international treaties on human rights and fundamental freedoms, international political treaties, international treaties of military nature, international treaties establishing the membership of the Slovak Republic in international organizations, international economic treaties of general nature, international treaties whose execution requires a law and international treaties which directly constitute rights or obligations of natural persons or legal persons to be valid, an approval of the National Council of the Slovak Republic is required prior to their ratification.

(5) International treaties on human rights and fundamental freedoms, international treaties whose executions does not require a law and international treaties which directly establish rights or obligations of natural persons or legal persons and which were ratified and promulgated in a manner laid down by law shall have primacy over the laws.

The original Art. 11, which had laid down the primacy of international human rights treaties if they provided for a more extensive human rights protection, was repealed in 2001. ${ }^{11}$ The same issue is now governed by Art. 7(5) and Art. 154c. Articles 17 and 18, which address personal liberty, were amended and the time limits for detention were prolonged from 24 hours to 48 and 72 hours. Furthermore, Art. 23(4) was amended to abolish the constitutional prohibition on extradition (or surrender) of citizens, and now reads: '(4) Every citizen has the right to freely enter the territory of the Slovak Republic. No citizen may be forced to leave his or her homeland or be expelled.' The last part of the provision which read 'or extradited to another state' was removed from the constitutional provision. ${ }^{12}$

Article 30 on the right to vote was amended to include the following last sentence in its first subparagraph: 'Foreigners with a permanent residence on the territory of the Slovak Republic have the right to vote and be elected in the self-administration bodies of municipalities and self-administration bodies of superior territorial units.' This provision goes further than required by EU law, since it does not limit the right to vote to EU citizens, but extends it to all foreigners who permanently reside in Slovakia.

Article 120 was amended to include a new subparagraph (2) which reads:

If so laid down by law, the Government is authorised to issue ordinances in order to execute the Europe Agreement establishing an association between the European Communities and their Member States, of the one part, and the Slovak Republic, of the other part, and to execute international treaties stipulated in Art. 7, para. 2 .

Article 125 on the powers of the Slovak Constitutional Court (SCC) was amended so that the referential framework for the constitutionality of legal acts includes not only the Constitution and constitutional laws, but also 'international treaties to which the National Council of the Slovak Republic has expressed its assent and which have been ratified and promulgated in the manner laid down by

\footnotetext{
${ }^{11}$ See Sect. 3.2.1 below for a detailed analysis of the former Art. 11 and its legal effects.

12 Thus constitutionally pre-empting much of the debate that later ensued in other Member States of the EU (e.g. Germany, Poland and the Czech Republic) about constitutional prohibitions on extraditing (surrendering) own citizens. See e.g. Komárek 2007 and Siegel 2008.
} 
law, ${ }^{13}$ This has been affirmed by a consistent line of case law of the SCC, which states that 'the competence of the Constitutional Court under Art. 125(1)(a) of the Constitution also includes international treaties that have been consented to by the National Council of the Slovak Republic and that have been ratified and promulgated as required by law'. ${ }^{14}$

However, the SCC has also ruled that if a provision is in breach of the Constitution, there is no need to further examine its alleged breach of any international instruments, since the potential breach of an international instrument would not bring any additional effects. ${ }^{15}$

Further, two new articles were inserted in the chapter on the SCC, of which Art. 125a bears relevance to EU accession and further EU developments:

(1) The Constitutional Court decides on the compliance of concluded international treaties for which consent of the National Council of the Slovak Republic is required with the Constitution or a constitutional law.

(2) A petition for a decision pursuant to para. 1 may be filed with the Constitutional Court by the President of the Slovak Republic or the Government before submitting the concluded international treaty for deliberation to the National Council of the Slovak Republic.

(3) The Constitutional Court decides on the petition pursuant to para. 2 within the period laid down by law; if the Constitutional Court by its decision expresses that the international treaty is not in compliance with the Constitution or a constitutional law, such international treaty may not be ratified.

Article 144 specifies which legal instruments are binding for judges when they decide cases. In its original version, it stated that judges were bound only by laws, and that in cases where it is so established by the Constitution or by law, judges were also bound by international treaties. After amendment, the article reads as follows:

(1) Judges are independent in the performance of their functions and bound solely by the Constitution, constitutional laws, international treaties stipulated in Art. 7, paras. 2 and 5 and laws.

(2) If the court is of the opinion that another generally binding legal regulation, its part or a particular provision related to the subject-matter of the proceeding contravenes the Constitution, constitutional laws, international treaties stipulated in Art. 7, paras. 2 and 5 or laws, it will interrupt its deliberations and submit a motion that a proceeding under Art. 125 , para. 1 be initiated. The finding of the Constitutional Court of the Slovak Republic is binding for all courts.

\footnotetext{
${ }^{13}$ However, it is important to note that even before the EU Amendment, the original Art. 125 included in the referential framework 'international treaties promulgated in a manner established for the promulgation of laws'.

${ }^{14}$ Judgment of the SCC, Pl. ÚS 10/14 (Data retention) of 29 April 2015, para. 70. Translation by the authors.

${ }^{15}$ See e.g. Judgment of the SCC, Pl. ÚS 3/09 (Health insurance) of 26 January 2011 and Pl. ÚS 10/14 (Data retention), n. 14.
} 
The last crucial article that was inserted by the EU Amendment in 2001 is Art. $154 \mathrm{c}$, which regulates the position of international treaties in the Slovak legal order and which reads as follows:

(1) International treaties on human rights and fundamental freedoms that [have been] ratified by the Slovak Republic and promulgated in a manner laid down by law before this constitutional law comes into effect are a part of its legal order and have primacy over [national] law, if they provide a greater scope of constitutional rights and freedoms.

(2) Other international treaties which [have been] ratified by the Slovak republic and promulgated as required by law before this constitutional law comes into effect are a part of its legal order, if so laid down by law.

Thus, the bulk of changes relating to the Slovak accession to the EU were carried out by the EU Amendment in 2001. As for subsequent constitutional changes relating to EU membership, in 2004, the Slovak legislator sought to regulate the relationships between the Government and Parliament in their participation in the EU legislative process, as well as the incompatibility of serving as an MP of the Slovak Parliament (the National Council of the Slovak Republic, hereinafter NCSR) and the European Parliament. Both of these provisions were originally included in the draft of Constitutional Act No. 140/2004. They did not, however, secure sufficient support in the NCSR and were removed from the draft. The incompatibility provision was nonetheless later included in Constitutional Act No. 323/2004 (adopted on 14 May 2004, in effect since 1 June 2004), and the relationship between the Government and Parliament was later provided for expressly by Constitutional Act No. 397/2004 on the cooperation of the National Council of the Slovak Republic and the Government of the Slovak Republic in EU matters (adopted on 24 June 2004, in effect since 1 August 2004). The latter constitutional amendment is different from the ones previously mentioned in that it did not directly alter the constitutional text, but rather exists as a self-standing piece of constitutional legislation.

1.2.2 The National Council of the Slovak Republic, i.e. the Slovak Parliament, is composed of one chamber, consisting of 150 Members of Parliament. For a constitutional amendment to be adopted, at least 90 MPs must support it. Pursuant to Art. 84(4) of the Constitution,

\footnotetext{
the agreement of at least a three-fifths majority of all Members of Parliament is required to pass and amend the Constitution and constitutional laws, to adopt an international treaty stipulated in Art. 7, para. 2, adopt [a] resolution on [a] public vote to remove the President of the Slovak Republic, file charges against the President and to declare war on another state.
}

This procedure, which is the only one for constitutional amendments, has been used for all previous constitutional amendments, including those related to the EU. 
Interestingly, draft constitutional laws cannot be vetoed by the President. The original wording of the Constitution was unclear on this point, but the provision has been amended to make this clear. ${ }^{16}$

1.2.3 After the political turmoil of late 1990s, including the problematic autocratic Mečiar-period, the main interest of the SR was to join the EU together with the other countries of the so-called Visegrad Group (the Czech Republic, Hungary and Poland). The EU was perceived as a club of 'rule of law countries', and joining the EU primarily meant becoming part of the political 'West'. From this point of view, accession in the 2004 wave of enlargement was a clear priority, with the discussion centring perhaps more on the practical form and wording of the constitutional amendments, but not questioning their aims or overall direction. Thus, the amendment process was perceived of as a rather straightforward 'technical' exercise in constitutional drafting. The advice of legal scholars and experts was no doubt present in the process of the legal drafting, since some of them were involved, in one way or another. For the size-related reasons outlined above in the Introductory Note and also due to the speed with which the EU Amendment was approved by the NCSR, no sizeable debate on the actual drafts could be discerned. For further details, see Sects. 1.2.1 and 1.5.

1.2.4 There have been no instances of EU-related proposals which have not materialised in practice. However, there have been two amendment proposals that were deflected in the legislative process. First, there was the proposed Constitutional Act No. 140/2004, discussed above in Sect. 1.2.1. As already explained, the substance of that proposal was subsequently put into different constitutional acts. Secondly, a similar moment occurred in 2011, when a draft constitutional act was being prepared with the aim of amending Constitutional Act No. 397/2004 Coll. (See Sect. 1.4.1 below for a detailed analysis of this act). The aim of the proposed amendment was to regulate the national procedures following an amendment of primary EU law pursuant to the special procedure foreseen by Art. 48(6) TEU. However, the necessary three-fifths majority was not found in the NCSR and the constitutional amendment was not adopted. Eventually, the contemplated change was nevertheless carried out in the form of an ordinary law amending the Rules of Procedure of the NCSR. Thus, the content of the provision made its way into the Slovak legal order, although endowed with lower legal force. $^{17}$

Currently, there are no EU-related amendment proposals being discussed or tabled. The reason for such absence might be the fact that, as outlined above in Sect. 1.2.1, the 2001 EU Amendment was quite detailed and explicit, thus, in contrast to more 'economic' EU amendments in other new Member States, limiting the need for further amendments and constitutional litigation.

\footnotetext{
16 Article 87(3) of the Constitution, as amended.

${ }^{17}$ For a more detailed analysis, see Jánošíková 2014.
} 


\subsection{Conceptualising Sovereignty and the Limits to the Transfer of Powers}

1.3.1 Within the Constitution the transfer of powers to the European Union is governed by Art. 7(2), which is EU-specific and allows the SR to 'transfer the exercise of a part of its rights to the European Communities and European Union'. The details and limits of this provision are discussed below in Sect. 1.3.3.

As for the legal effects of EU law, the relevant general provision is Art. 1(2), which states that the SR shall respect its international obligations. The legal effects of primary EU law are not addressed specifically by the Constitution, but the EU Treaties may be classified as 'international treaties whose execution does not require a law' and 'international treaties which directly establish rights or obligations of natural persons or legal persons', which are the terms used in Art. 7(5). The EU Treaties thus 'shall have primacy over the laws', as expressly laid down in the second sentence of Art. 7(5).

The position of EU primary law in the Slovak legal order has been contested by academic writers, and this issue has been also addressed in quite a confusing way by the SCC. Some authors ${ }^{18}$ have argued that primary EU law derives its legal effects from Art. 7(2) of the Constitution, while other authors ${ }^{19}$ would rather place primary EU law under the regime of Art. 7(5) of the Constitution. Even the SCC has changed its position in this regard over time. In its decision on health insurance companies (discussed in more detail below in Sect. 1.3.4), the SCC stated that 'although the notion of "legally binding acts" used in the second sentence of Art. 7(2) of the Constitution could give rise to problems when defining its exact scope, it can undoubtedly be concluded that the TFEU is such a legally binding act' ${ }^{20}$ According to the SCC, the TFEU falls into a 'special subcategory of international treaties' through which the SR has transferred competences to the EU and which are thus governed by Art. 7(2). ${ }^{21}$ However, treaties falling within this special subcategory still qualify as 'international treaties to which consent [has been] given by the NCSR and which [have been] ratified and promulgated in a manner laid down by law', which means that they still belong to the referential framework of constitutional review, as is set out in Art. 125 of the Constitution. The SCC has, however, departed from this position in its more recent case law (see the data retention judgment discussed below).

\footnotetext{
${ }^{18}$ See for example Drgonec 2013. Drgonec claims that 'legally binding acts' comprise primary EU law and those acts of secondary EU law that are directly applicable, i.e. regulations and decisions.

${ }^{19}$ See for example Jánošíková 2014, according to whom the notion of 'legally binding acts of the EC/EU' only refers to legal acts that have been 'made by the EC/EU', while primary EU law derives its effects from Art. 7(5), rather than Art. 7(2).

${ }^{20}$ Judgment of the SCC, Pl. ÚS 3/09 (Health insurance), part V.3.4.

${ }^{21}$ Ibid.
} 
Yet, despite all these disagreements, other authors note that this taxonomic dispute is quite pointless, ${ }^{22}$ since the effects of primary EU law are nevertheless determined by EU law itself and are not dependent on a constitutional recognition in one provision or another. These authors believe that primary EU law is more likely to fall within the regime of Art. 7(5) of the Constitution, but it is in fact not excluded that it can also be covered by the provision in Art. 7(2). These two subsections are not necessarily mutually exclusive. The preference for categorisation under Art. 7(5) follows from the fact that the NCSR, upon giving consent to both the Accession Treaty and the Lisbon Treaty, also declared that these treaties are international treaties in the sense of Art. 7(5) of the Constitution. ${ }^{23}$

This latter position has also been confirmed in a recent case concerning the constitutionality of the data retention provisions, in which the SCC stated the following:

The position of the founding EU Treaties (TEU and TFEU) in the Slovak legal order is governed by Art. 1(2) and Art. 7(5) of the Constitution. Article 7(5) lists the categories of international treaties that have primacy over laws. The founding EU Treaties can undoubtedly be included in these categories. Even the Charter, which has the same legal force as the founding Treaties, must thus have the same position in the Slovak legal order as is given by Art. 7(5) of the Constitution to the listed categories of international Treaties. More precisely, the Charter must be assigned such legal position in the Slovak legal order as is assigned to international treaties on human rights and fundamental freedoms under Art. 7(5) of the Constitution. ${ }^{24}$

The SCC derives this conclusion also from Art. 6(1) TEU. ${ }^{25}$

The situation is slightly different with regard to secondary EU law. It also explicitly has primacy over Slovak laws, but the constitutional basis for this is different, and is provided for in the second sentence of Art. 7(2), which states that 'legally binding acts of the EC/EU shall have primacy over the laws of the Slovak Republic'. The notion of 'legally binding acts' is a concept of Slovak constitutional law that does not correspond to any established concept of EU law, which has caused considerable confusion. ${ }^{26}$ One thing that is clear is that from the point of view of the Constitution, all these provisions establish the explicit primacy of EU

\footnotetext{
${ }^{22}$ See Bröstl 2013, p. 97.

${ }^{23}$ See Decision of the NCSR No. 365 of 1 July 2003 in the case of the Accession Treaty, and Decision of the NCSR No. 809 of 10 April 2008 in the case of the Lisbon Treaty.

${ }^{24}$ See Judgment of the SCC, Pl. ÚS 10/14 (Data retention), n. 14, para. 69. The position of the EU Charter is then further developed in paras. 70-72 of the judgment, and the SCC concludes quite strongly in para. 73 that EU Treaties clearly fall within Art. 7(5) of the Constitution. The SCC also refers to the two decisions of the NCSR, which have categorised EU primary law as falling under Art. 7(5) of the Constitution. Translation by the authors.

${ }^{25}$ See para. 73 of the Judgment: 'On the basis of Art. 6(1) TEU, which assigns to the Charter the same legal power as to the founding Treaties, the Charter is to be given the same legal position in the Slovak legal order as is given to international treaties under Art. 7(5) of the Constitution. These are undoubtedly also treaties that fulfil the criteria of Art. 125(1) of the Constitution.' Translation by the authors.

${ }^{26}$ See Drgonec 2013 and Jánošíková 2014, who have presented two differing points of view.
} 
law only over the sub-constitutional norms of the domestic legal order, while the Constitution (and the SCC) remains silent on the hierarchy between EU norms and domestic norms of constitutional nature. ${ }^{27}$

1.3.2 The question of absolute versus relative sovereignty has not yet been addressed by the SCC. It remains a matter of (future?) interpretation whether Art. 7 has transformed the notion of sovereignty from an absolute into a relative one.

It may be only added that such an (inherently political) assessment of the nature of constitutional sovereignty can hardly be inferred from any national constitutional provisions, but will always be dependent first on the particular case and, secondly, on the overall political and legal climate in the Member State in question and within the Union itself at a given moment. To provide an extreme example: in its Lisbon II decision, ${ }^{28}$ the Czech Constitutional Court announced its 'shared' or 'pooled' sovereignty vision of Czech constitutionality, for which it was greatly praised in (constitutional pluralist) academic circles Europe-wide. Three years later in Holubec, ${ }^{29}$ the very same court announced something quite different, in effect reaffirming a de facto absolute (and quite isolationist) view of sovereignty. Needless to say that the text of the Czech Constitution itself did not change in the course of those three years. Presently, not only legal scholarship may harbour some doubts as to how to 'interpret' and 'conceptualise' such an approach in general terms. ${ }^{30}$

1.3.3 As to the limits to the delegation of powers, the wording of Art. 7(2) suggests that Slovakia may only transfer 'the exercise of a part of its rights' to the EC/EU. The provision raises two interesting questions. First, it speaks not about transfer of powers, but rather about transfer of the exercise of rights. (This wording is similar to that of the Belgian or Luxembourgish constitutional texts.) Secondly, it follows from the wording that any transfer must not entail all the rights, but be limited to $a$ part thereof. These seem to be the two most obvious and textual limits of Art. 7(2).

The preceding paragraph, Art. 7(1), deals with a more significant change in sovereignty, namely entering into and withdrawing from a 'state union' with other states. Such a decision would have to be made in the form of a constitutional law, confirmed by a referendum.

\footnotetext{
${ }^{27}$ Drgonec 2013 has argued that 'European law has primacy over laws, but not over the Constitution. This conclusion can be derived from the legal opinions of the SCC, although these did not concern Art. 7(2) directly, but were aimed more generally at the relationship of the Slovak Constitution and international treaties, where the SCC attributed to the international treaties merely the role of an interpretation tool'. The unanswered question remains, however, how far the legal effects of EU law may be derived from the legal effects of international treaties in general. On the other hand, this may reflect the endless and ongoing controversy between 'internationalist' and 'Europeanist' views on EU law and its nature - contrast e.g. the opposing views relating to the EU-law-character-narrative of De Witte 2012 and Walker 2012.

${ }^{28}$ Judgment of the Czech Constitutional Court of 3 November 2009, Pl. ÚS 26/06, in English online at www.usoud.cz. Further see Komárek 2009.

${ }^{29}$ Judgment of the Czech Constitutional Court of 31 January 2012, Pl. ÚS 5/12, online at www. usoud.cz. Further e.g. Zbíral 2012 or Bobek 2014.

${ }^{30}$ Recently e.g. Přibáň 2015, pp. 323-348.
} 
The SCC dealt with this issue in its decision II. ÚS 171/05 (EU Constitutional Treaty), in which the Court considered whether the Slovak membership in the EU could fall within the scope of Art. 7(1) rather than Art. 7(2). This case arose from a constitutional complaint of a number of natural persons (associated with the Conservative Institute of Milan Rastislav Štefánik), who claimed that the EU Constitutional Treaty transformed the Union into a federation and thus a 'state union'. The ratification of the Constitutional Treaty by the SR should therefore have been subjected to an obligatory referendum, as required by Art. 7(1). The claimants argued that by not organising a referendum, the NCSR had breached their constitutional right to participate in the governance of public affairs.

The SCC disagreed with such claims, stating that even after the changes brought about by the EU Constitutional Treaty, the Union is not a 'state' in the sense of Art. $7(1)$ of the Slovak Constitution, and that the EU Treaties, including the Constitutional Treaty, were correctly subjected to the regime of Art. 7(2). The SCC further added that

...the developments in the EU undoubtedly proceed in the direction of a future state, i.e. a state union, but the Constitutional Court believes that at present, it is impossible to predict, at which concrete moment this transformation will take place. The evidence in these proceedings revealed that the EU shows already at present a whole range of features and functions, which can be seen ... as features of a state union.

Having said that, the SCC concluded that

all the future acts and steps that the SR will take in the framework of its relationship with the ... European Union, must be governed by the provision of Art. 7(2) of the Constitution. This would not be different even if the act were such as to change the qualitative parameters of the cooperation between the members of the given organisation, which is the case of the [Constitutional] Treaty. Therefore, irrespective of the character of the EU, neither the accession of the SR to the EU nor any other act initiated either by the EU or by the SR, could lead to a situation that would coincide with the aim or the content of Art. 7(1) of the Constitution. $^{31}$

This conclusion is rather surprising, since it postulates either that the EU can never in the future become a 'state union' in the meaning of Art. 7(1) of the Slovak Constitution, or that even if it one day were to become such 'state union', the Slovak Constitution would nevertheless treat it, irrespective of its change in quality, as a mere 'international organisation' within the meaning of Art. 7(2) and without the need for a referendum. Both statements appear to be highly speculative and ought to be treated as a mere obiter, hardly apt for fixing the situation immutably for the future.

1.3.4 The Constitution does not address the relationship between EU law and Slovak constitutional law. It only recognises the primacy of EU law over (sub-constitutional) domestic legal norms. So far, there has not been any direct

\footnotetext{
${ }^{31}$ Judgment of the SCC, II. ÚS 171/05 (EU Constitutional Treaty) of 27 February 2008.
} 
conflict between an EU law norm and a norm of Slovak constitutional law, so the question of the supremacy of the Constitution remains open.

Interestingly, however, a practical example of the presence of such a conflict can be found already in the Constitution itself. Pursuant to Art. 144(2) thereof, a judge who thinks that a provision of Slovak law is in conflict with an international treaty in the sense of Art. 7(5) of the Constitution (which includes the EU Treaties), shall suspend proceedings and refer the case to the SCC. This requirement seems to be in direct conflict with the Simmenthal ${ }^{32}$ ruling of the Court of Justice, and potentially also with the more recent Melki and Abdeli ${ }^{33}$ judgment.

Even the SCC has acknowledged that in a situation like this, the ordinary court facing a conflict of a Slovak norm and a European norm should not refer the case to the SCC, but should rather follow the doctrine of Simmenthal. In its decision in case Pl. ÚS 3/09 (Health insurance), the SCC first quoted from the Court of Justice's rulings in Costa and Simmenthal, explaining the principle of primacy of EU law over domestic law and its practical effects for ordinary courts. It then noted that if an ordinary court is confronted with a conflict between a domestic legal norm and a provision of EU law, the judge is

under a duty to give full effect to [the provision of EU law], if necessary refusing of its own motion to apply any conflicting provision of national legislation, even if adopted subsequently, and it is not necessary for the court to request or await the prior setting aside of such provision by legislative or other constitutional means. ${ }^{34}$

In a similar vein, the last sentence of Art. 144(2) provides that ' $[\mathrm{t}] \mathrm{he}$ finding of the Constitutional Court of the Slovak Republic is binding for all courts'. In its decision in Križan, ${ }^{35}$ the Grand Chamber of the Court of Justice indirectly negated this provision by stating that

a national court, such as the referring court [the Supreme Court of the Slovak Republic authors] is obliged to make, of its own motion, a request for a preliminary ruling to the Court of Justice even though it is ruling on a referral back to it after its first decision was set aside by the constitutional court of the Member State concerned and even though a national rule obliges it to resolve the dispute by following the legal opinion of that latter court. ${ }^{36}$

These remain, however, points of potential conflict, so far limited to the pronouncements of the Court of Justice, but left 'unanswered' in any way by the SCC.

On a general note, however, it could be said that the SCC is an 'EU-friendly' court, as far as any generalisation of similar type may be made. Sometimes its judgments seem to be even overly optimistic towards EU law (e.g. the above-mentioned ruling in the case Pl. ÚS 3/09 (health insurance) or Pl. ÚS 10/14 (data retention), which both show willingness to include EU law and even

\footnotetext{
${ }^{32}$ Case 106/77 Amministrazione delle Finanze dello Stato v. Simmenthal [1978] ECR 00629.

${ }_{33}$ Joined cases C-188/10 and C-189/10 Aziz Melki and Sélim Abdeli [2010] ECR I-05667.

${ }^{34}$ Judgment of the SCC, Pl. ÚS 3/09 (Health insurance) of 26 January 2011.

${ }^{35}$ Case C-416/10 Križan and Others [2013] ECLI:EU:C:2013:8, paras. 62-73.

${ }^{36}$ Ibid., para 73.
} 
international law in the referential framework for the SCC), but it is too early to deduce any general conclusions from the case law.

\subsection{Democratic Control}

1.4.1 The role of the Slovak Parliament in EU matters is defined by the Constitution, by Constitutional Act No. 397/2004 Coll. on the cooperation of the NCSR and the Government of the SR in EU matters, and by Act No. 350/1996 Coll. on the rules of procedure of the NCSR. ${ }^{37}$

At the moment of accession, the involvement of the NCSR and the cooperation between the NCSR and the Government in EU matters had not been settled in any way. This gap was filled shortly after accession, in June 2004, by the adoption of Constitutional Act No. 397/2004 Coll. It is a very short act, consisting of only four articles, aimed primarily at defining the respective powers of the NCSR and the Government in EU matters.

Pursuant to Art. 1, the Government has an obligation to inform the NCSR about the current EU agenda, about any draft legislation debated at the EU level, and about any draft opinions (draft EU legislation) or positions that are to be presented in the name of the SR. Pursuant to Art. 2, the NCSR may endorse any such draft opinions, and any other opinions in EU matters. If the NCSR does not issue an opinion within two weeks, it is presumed that it has endorsed the Government's opinion. Furthermore, Art. 2(4) states that a parliamentary decision shall be legally binding for any member of the Government, and Art. 2(5) allows for an exception from this principle in pressing cases, in which case the member of the Government must act in the interest of the SR without delay, but is subsequently obliged to inform the NCSR of the action. The Constitutional Act also requires a regular parliamentary deliberation on EU matters that is to take place at least once a year, on the basis of a report proposed by the Government. This discussion should result in a set of recommendations given by the NCSR to the Government for the following year.

Although the above-mentioned Constitutional Act undoubtedly strengthened the position of the NCSR in EU matters, it should be pointed out that the Government played a major role in the approximation of the Slovak legal system to the EU legal system before accession, and continued to play a major role in the transposition of certain EU legal acts after accession. Pursuant to Art. 7(2), third sentence, and Art. 120(2) of the Constitution, the Government has 'the power to issue regulations to implement laws'. This power is fleshed out further by Act No. 19/2002 on the conditions of issuing governmental regulations, which defines in its Art. 2(1) the specific areas in which a governmental regulation may substitute a legislative

\footnotetext{
${ }^{37}$ For a detailed study of the respective roles of the Parliament and the Government in EU matters, see Bartovič 2010.
} 
transposition of EU law measures. These are custom duties; banking legislation; corporate accountancy and taxation; intellectual property; protection of workers; financial services; consumer protection; technical regulations and norms; use of nuclear power; transportation; agriculture; environment; and free movement of labour. In practice, this brings about a major decrease in the parliamentary workload, and it shifts the burden of transposition from the legislative to the executive branch. It also proves that transposition of EU norms is seen as a technical issue, rather than a politically sensitive one. However, pursuant to Art. 2(2) of the Act, such governmental regulations cannot regulate fundamental rights and freedoms, the state budget or other matters where the Constitution requires a law, and also cannot create new state institutions.

As for the practical organisation of the EU agenda in the NCSR, Art. 45 of the Rules of Procedure of the NCSR allows the NCSR to create specialised committees. On the basis of this provision, the NCSR created the Committee for European Affairs (CEA) in April 2004. Before the creation of the CEA, EU matters had been dealt with by the Foreign Committee, the Constitutional and Legal Affairs Committee, and the Committee for European Integration. ${ }^{38}$ The Rules of Procedure of the NCSR were then amended to include a separate provision on the CEA, namely Art. 58a, which provides for the composition of the committee (proportionate representation of all the parliamentary political parties), its competences and various procedural matters. The CEA currently consists of 15 members and 15 substitute members, it functions continuously (unlike other committees) and it is one of the busiest parliamentary committees. However, there is quite a difference between the formally strong position of the CEA and its actual weight. The main problems are: lack of interest in the EU agenda, low administrative and expert capacity to handle the EU agenda, late involvement of the Parliament in the creation of positions and the fact that the CEA members are simultaneously members of other parliamentary committees, which leaves them with little time to focus on the CEA agenda. ${ }^{39}$

1.4.2 In 2003, the SR held a referendum on accession to the European Union. The question was worded as follows: 'Do you agree to the Slovak Republic becoming a Member State of the European Union?' In total, 52.15\% of registered voters participated in this referendum, $92.46 \%$ of whom voted in favour of the accession and $6.2 \%$ against. It is noteworthy that out of the eight referendums that have been organised in the history of the independent Slovak Republic, this was the only one where the required turnout threshold (higher than 50\%) was reached.

Since the accession to the EU is governed by Art. 7(2) of the Constitution rather than by Art. 7(1), a referendum was actually not constitutionally required. Therefore, even if the required turnout had not been reached, the accession would have been possible. However, if a majority of voters had voted no (and if the

\footnotetext{
${ }^{38}$ Ibid.

${ }^{39}$ Ibid. The name of this expert report ('Giant in Theory, Dwarf in Practice') gives a clear indication of this.
} 
turnout had been high enough), the Parliament would have been able to change the outcome of the referendum only after the lapse of a three-year time limit.

In the case of the EU Constitutional Treaty and the Lisbon Treaty, no referendum was held. An analysis of the constitutional complaint in relation to the failure to hold a referendum in the case of the EU Constitutional Treaty was provided in Sect. 1.3.3 above.

\subsection{The Reasons for, and the Role of, EU Amendments}

1.5.1 There was some academic discussion concerning the need for a constitutional amendment in relation to the Slovak accession to the EU. Although some authors argued that an amendment was not absolutely necessary, the prevailing opinion seemed to be that the Constitution should be amended in order to prepare the Slovak legal order for membership in the EU.

Again, as already explained above, due to the overwhelming political support for the SR to emerge from the Mečiar-period and accede to the EU in the 'first wave' (see Sect. 1.2.3 above), the 2001 EU Amendment was seen as a constitutional necessity, an exercise in quick constitutional drafting, and did not spur much of any of the indicated types of debates.

1.5.2 Since the Slovak Constitution was amended significantly prior to the Slovak accession to the EU, this question is not relevant in the Slovak context.

1.5.3 Perhaps as in any federated structure, within which the individual units have their own rules, the role of national constitutions remains the same as it has always been: in the bottom-up direction, it is one of initiative and inspiration; in the top-down direction, it is largely one of control and checks and balances. Intriguingly, in its horizontal dimension, it may be both. Thus, looking at the European constitutional reality empirically rather than normatively, the Member States, driven by their constitutional ideas and backgrounds, have been operating as both the initiators and the inspiration for change at the European level. Conversely, national constitutions, their provisions and the values enshrined therein have always been the guiding principles for both national interpretation of EU law and a potential resistance to it on the national level.

Such ongoing interaction between the layers in Europe, in the recent two decades enlarged by its horizontal dimension (the Member States being obliged by the EU to recognise and to enforce decisions of other Member States in various fields and areas) does not perhaps necessitate explicit constitutional amendments. These are of course possible, on both levels, but not, strictly speaking, necessary. They are also not necessarily one-directional, as the question would imply, i.e. that the Member States would have to alter their values and convictions under the impact of the EU and other international organisations. Member States, or a number of them, 
acceded in 'clusters', which might possibly lead to a 'qualified revolt' whereby the Member States might push the European or international level towards a constitutional change, not necessarily vice-versa. ${ }^{40}$

\section{Constitutional Rights, the Rule of Law and EU Law}

\subsection{The Position of Constitutional Rights and the Rule of Law in the Constitution}

2.1.1 The Slovak Constitution includes a full catalogue of fundamental rights in its Chap. II (Arts. 11-54). This chapter is divided into eight sub-chapters (general provisions; fundamental human rights and freedoms; political rights; rights of national minorities and ethnic groups; economic, social and cultural rights; environmental and cultural heritage rights; the right to judicial protection; concluding provisions). The Slovak human rights catalogue is thus rather comprehensive, spelling out in detail the individual rights that are guaranteed on the constitutional level.

General principles of law (in the more traditional, narrower sense, i.e. excluding human rights but including a range of principles such as legal certainty, non-retroactivity, protection of good faith, etc.) are not explicitly listed in the Slovak Constitution. They are, however, universally understood as components or elements of the rule of law principle (or, rather, in the continental context, of the Rechtsstaat principle), as established in Art. 1(1) of the Constitution (see Sect. 2.1.3 below), and as such applied by the courts.

As for the enforceability of fundamental human rights, Art. 12(2) of the Constitution lays down that fundamental rights and freedoms 'are guaranteed to everyone'. The most robust way of enforcing one's rights is through judicial protection, both in ordinary courts and before the SCC. Pursuant to Art. 127(1) of the Constitution, the SCC 'shall decide on complaints by natural persons or legal persons objecting to violation of their basic rights and freedoms ... unless another court shall make decisions on the protection of such rights and freedoms'. Furthermore, fundamental rights and freedoms also enjoy constitutional protection by the Prosecutor's Office of the SR (by virtue of Arts. 149-151) and by the Ombudsperson (by virtue of Art. 151a).

Moreover, since the SCC understands fundamental rights to impose positive obligations on the state, these in turn bind (and ought to be upheld) by all state bodies and authorities. As the SCC stated in its decision in II. ÚS 8/96 (abduction of Michal Kováč Jr),

${ }^{40}$ For examples, see e.g. Bobek 2017. 
[t]he rights and freedoms embedded in the Constitution of the Slovak Republic are protected by a positive obligation. The content of this positive obligation of the state in relation to rights and freedoms of a citizen is the duty to take measures to protect the rights that have been guaranteed to citizens in the Constitution. ${ }^{41}$

2.1.2 The general constitutional provisions on limiting rights and imposing duties are set out in Art. 13 of the Constitution. It reads as follows:

(1) Duties may be imposed

(a) by statute or on the basis of a statute, within its limits, and while complying with basic rights and freedoms,

(b) by international treaty pursuant to Art. 7, par. 4 which directly establishes rights and obligations of natural persons or legal persons, or

(c) by government ordinance pursuant to Art. 120, para. 2.

(2) Limits to basic rights and freedoms may be set only by a statute under conditions laid down in this Constitution.

(3) Legal restrictions of basic rights and freedoms must apply equally to all cases which meet prescribed conditions.

(4) When restricting basic rights and freedoms, attention must be paid to their essence and meaning. These restrictions may only be used for the prescribed purpose.

The general rights limitation clause is thus quite robust. It contains all the limitations one normally associates with the (largely German-styled) rights-limitation clause. Most importantly, Art. 13(1)(a) and 13(2) provide for 'Gesetzesvorbehalt' - limits to rights and the imposition of duties are generally permissible only by a statute, i.e. an Act of Parliament, not by an executive decree although letters (b) and (c) do water down this original limitation somewhat. Furthermore, Art. 13(4) protects the essence of the rights and prevents their 'hollowing out'.

In addition to these general rights-limitation provisions, there are also specific (or sectoral) limitations of rights. In addition to Art. 7(4) and Art. 120(2), which are mentioned explicitly in the first paragraph of Art. 13, there are other constitutional provisions that limit rights, such as Art. 17 on the conditions of detention, Art. 25(1) on compulsory military service, Art. 42(1) on compulsory school attendance and Art. 54 on restrictions on the entrepreneurial activities of certain professions and restrictions on the right to strike.

As a 'limit to the limit', there is Art. 2(2), which establishes that 'state bodies may act only on the basis of the Constitution, within its limits, and to the extent and in a manner which shall be laid down by law'. Therefore, the state cannot limit fundamental rights and freedoms without an express entitlement by the Constitution or by a law.

\footnotetext{
${ }^{41}$ Judgment of the SCC, II. ÚS 8/96 (Abduction of Michal Kováč Jr) of 4 September 1996.
} 
Finally, the Constitution also includes a specific 'procedural limit' as to changes to the constitutional system: pursuant to Art. 93(3), fundamental rights and freedoms cannot form the subject matter of a referendum.

2.1.3 The rule of law Article 1(1) of the Constitution states that the SR is a sovereign, democratic state governed by the rule of law'. This principle is perhaps closer, both in its wording and in its content, to the German concept of Rechtsstaat, rather than the common law concept of the rule of law. The elements of this principle are not spelled out in the Constitution, but courts (especially the SCC) often refer to the 'rule of law principle' in their reasoning. They treat the principle as an umbrella concept that includes various general principles of law (e.g. legal certainty, legitimate expectations, the prohibition of (true) retroactivity, etc.).

Over the years, the SCC has expanded the rule of law into one of the robust constitutional principles. For example in PL. ÚS 3/00, the SCC opined that:

The rule of law principle also includes the citizens' trust in the legal order. In principle, it is necessary to protect the trust that the legal consequences that follow from unchanging factual circumstances are recognised (and remain recognised). However, the protection of such trust does not apply in cases where trust in a certain legal state would not be substantively justified, i.e. the rule of law principle does not protect a citizen from every subjectively perceived loss of trust or from every disappointment. ${ }^{42}$

Moreover, in its decision in PL. ÚS 17/08, the SCC subscribed to a material notion of the rule of law:

The material rule of law concept includes a requirement of substantive quality and value quality of a legal norm, which is to ensure that the legal instrument, as implemented in the chosen legislative regulation, is adequate in relation to the legitimate aim pursued by the legislator, and that the chosen legislative measure is compatible with constitutional principles and democratic values. ${ }^{43}$

Thus, the rule of law is in practice both frequently invoked by applicants and also frequently employed by the courts in their reasoning. Its specific components tend, however, to be quite rich and variable.

Judicial protection The right to access to a court is embedded in Art. 46 of the Constitution. It reads as follows:

(1) Everyone may claim his right in a manner laid down by law in an independent and impartial court and, in cases laid down by law, at another body of the Slovak Republic.

(2) Anyone who claims to have been deprived of his rights by a decision of a public administration body may turn to the court to have the lawfulness of such decision re-examined, unless laid down otherwise by law. The re-examination of decisions concerning basic rights and freedoms may not, however, be excluded from the court's authority.

\footnotetext{
42 Judgment of the SCC, Pl. ÚS 3/00 (Land ownership) of 24 April 2001.

${ }^{43}$ Judgment of the SCC, Pl. ÚS 17/08 (Rule of law) of 20 May 2009.
} 
(3) Everyone is entitled to compensation for damage incurred as a result of an unlawful decision by a court, or another state or public administration body, or as a result of an incorrect official procedure.

(4) Conditions and details concerning judicial and other legal protection shall be laid down by law.

This right has been given a rich and wide interpretation from the very beginning. Its connection with the rule of law principle is obvious for example from the decision of the SCC in case I. ÚS 4/94, in which the Court stated: 'the right to judicial protection is not exhausted by a victory in a civil dispute; the right to judicial protection also means that the courts are bound by law, both procedurally and substantively. ${ }^{44}$ The flipside of this argument has been expressed by the SCC in case I. ÚS 6/97: '[t]he practice of a judicial institution, which acts in accordance with substantive and procedural provisions of law, cannot establish a breach of a fundamental right embedded in Art. 46(1) of the Constitution'. ${ }^{4}$

Publication of legislation As a general rule, in order to become valid law, legal acts must be duly published in the Collection of Laws. With regard to Slovak laws (statutes), this principle is provided for in Art. 1 of Act No. 1/1993 Coll., on the Collection of Laws of the Slovak Republic. Moreover, the duty to make statutes accessible to the public may be seen, on the constitutional level, as an emanation of the principle of the rule of law, provided for in Art. 1(1) of the Constitution. ${ }^{46}$ For a more detailed examination of the issue of unpublished legislation, refer to Sect. 2.5 below.

Limitation of rights Finally, as already outlined in Sect. 2.1.2 above, Art. 13 of the Constitution expressly provides, in the form of a provision on limitation of rights, that duties and obligations (which naturally also include sanctions and penalties) may be provided for only by a statute, i.e. an Act of Parliament. However, this previously categorical limitation has been watered down by the EU Amendment, which put international treaties into a similar category under Art. 7(4), but most importantly did the same for government ordinances, pursuant to Art. 120(2). The latter category includes government ordinances that are adopted for the implementation of EU measures in given areas (further above in Sects. 1.2.1 and 1.4.1).

\subsection{The Balancing of Fundamental Rights and Economic Freedoms in EU Law}

2.2.1 As to the balancing of fundamental rights with economic free movement rights, the question cannot be usefully answered if it is framed in this way. First, as

\footnotetext{
${ }^{44}$ Judgment of the SCC, I. ÚS 4/94 (Judicial protection) of 27 October 1994.

45 Judgment of the SCC, I. ÚS 6/97 (Judicial review) of 23 January 1997.

${ }^{46}$ See e.g. Hodás 2008, p. 527.
} 
a general matter, courts are typically not allowed to frame the answer in the way they please, but have to frame it according to the structure of the case that is brought before them. The role of the given court and the type of cases it receives also pre-determine what will be the 'basic rule' and what will be its 'limitation' or 'exception'. Thus, since the Court of Justice of the European Union (CJEU) is not a general human rights court, the cases brought before it come as 'economic' cases free movement is the basic rule and other values and interests are the limitations. That is logical and relates to the competence and the field of application of EU law: there must first be an EU law (economic) element and only then can any human rights considerations be triggered, at least certainly as far as Member States' measures are concerned, which was also the case in both Omega ${ }^{47}$ and Schmidberger ${ }^{48}$ Conversely, national constitutional courts are human rights courts. Thus, cases brought before them are pleaded primarily on human rights grounds, with other values and interests providing the permissible limitations or exceptions.

From this point of view, the 'structure' of the case is given by the nature of the court. The idea presented by some of the critiques of the Court's decision in Viking ${ }^{49}$ and Laval, ${ }^{50}$ namely that the Court of Justice 'prioritised' the economic freedom over social rights because the economic free movement was the rule and fundamental rights the exception, demonstrates considerable disregard for the competence of the CJEU. A case may fall into the competence of the CJEU only if it is presented as an 'economic' case. The (primary) freedom invoked is bound to be 'economic', i.e. one of the four freedoms, in order for the case to fall within the scope of application of EU law. Reversing the rule with the exception could amount to asserting a general human rights competence by the CJEU, so dreaded by all the Member States and a substantial number of legal scholars.

Conversely, a national constitutional court will always approach a case submitted to it with the primary vantage point of the fundamental right in question, to which EU law and economic freedoms might provide legitimate exceptions. The SCC has not yet ruled on the specific balance between fundamental rights and EU economic freedoms, but balancing human rights with economic interests generally is a common exercise performed by the Court. Thus, for example, in a case dealing with the alleged unconstitutionality of expropriation due to the construction of highways, the SCC reasoned by a typical proportionality test, presented in four consecutive steps: (1) is there a fundamental right at stake? (2) is there an interference with such fundamental right? (3) is the interference lawful? (4) does the interference satisfy the test of proportionality, i.e. the conditions of legitimate aim,

\footnotetext{
${ }^{47}$ Case C-36/02 Omega [2004] ECR I-09609.

${ }^{48}$ Case C-112/00 Schmidberger [2003] ECR I-05659.

${ }^{49}$ Case C-438/05 The International Transport Workers' Federation and The Finnish Seamen's Union [2007] ECR I-10779.

${ }^{50}$ Case C-341/05 Laval un Partneri [2007] ECR I-11767. For a summary of this traditional 'labour law' or 'human rights' critique of both decisions, see Introduction in Freedland and Prassl 2014.
} 
suitability, necessity and proportionality in the strict sense $?^{51}$ The Act on Highway Construction that provided for the possibility of exploitation for the purpose of highway construction was eventually struck down by the SCC on the grounds of the necessity condition. The SCC observed in para. 74 of the judgment that the adopted measures were certainly not the least restrictive way to reach the desired aim.

From the above, follows the second point: since the two courts have differently defined jurisdiction, the 'adjustment' potential is rather limited. The CJEU will not receive primarily human rights cases (since these are outside its competence, unless they have some other link with EU law), and national constitutional courts will not deal with free movement or other economic cases if they have no primary fundamental rights element (they will declare these to be devoid of a constitutional dimension and for the ordinary courts to deal with). This does not preclude, however, that each of the actors might be more ready to take the interests and concerns from the other 'box' into account in its balancing exercise. However, no such distinct change can be traced in the case law of the SCC and, on a general level, would be difficult to expect.

\subsection{Constitutional Rights, the European Arrest Warrant and EU Criminal Law}

Constitutional framework The Slovak Constitution offers an extensive and detailed framework for principles of criminal law, including issues such as personal freedom and limits to deprivation of liberty (Art. 17), access to courts (Art. 46), defence rights (Arts. 47-48), nulla poena sine lege (Art. 49) or the presumption of innocence and the ne bis in idem principle (Art. 50).

Implementation of the European Arrest Warrant (EAW) in Slovakia European criminal law has brought a number of major changes into the Slovak legal order. As has been explained in Sect. 1.2.1 above, the Slovak Constitution was amended in 2001 so that the prohibition of surrendering a citizen to another state was removed from the provision of Art. 23(4) of the Constitution, without any further guarantees or limits. This solution may seem overly enthusiastic and it has been criticised as lacking the necessary constitutional guarantees, such as are provided for example in Art. 16(2) of the German Constitution. ${ }^{52}$ On the other hand, it might be added that the EU amendment was adopted in 2001, i.e. before the adoption of the EAW Framework Decision 2002/584/JHA. ${ }^{53}$ The reason for the Slovak amendment at that time was the pending ratification of the Statute of the International Criminal

\footnotetext{
${ }^{51}$ See Judgment of the SCC, No. Pl. ÚS 19/09 (Highways) of 26 January 2011, para. 69; see also para. 74.

${ }^{52}$ See Hodás 2011, pp. 68-69.

${ }^{53}$ Council Framework Decision of 13 June 2002 on the European arrest warrant and the surrender procedures between Member States (2002/584/JHA), [2002] OJ L 190/1.
} 
Court and not the EU EAW Framework Decision, which, at the time, had been contemplated but not yet adopted.

On the national sub-constitutional level, the EAW Framework Decision was first transposed into the Slovak legal order by Act No. 403/2004 Coll., on the European Arrest Warrant. The practice subsequently showed that this implementation was insufficient in various regards - it failed to transpose some of the EAW provisions comprehensively, it was not systematic enough and it was too rigorous in matters of detention for some types of crimes. ${ }^{54}$ This act was therefore repealed and replaced by Act No. 154/2010 Coll., on the European Arrest Warrant (currently in force), which corrected these insufficiencies. The new Act built on the existing terminology introduced in the original Act, but it introduced a new systematic structure that should be more in line with the practical experience in the field. ${ }^{55}$ The most important change, from a procedural point of view, was the introduction of preliminary detention (Art. 15 of Act No. 154/2010 Coll.), inspired by the provisions of the criminal code that regulate extradition. Substantively, the crucial change was the inclusion of a proportionality clause in Art. 5(3) of the Act, which states: 'A court shall not issue a European arrest warrant if it is clear before such issuance that the requesting of the person from a foreign country would cause a degree of harm disproportionate to the significance of the criminal proceedings or to the consequences of the criminal act.'

The SCC has not yet had a chance to (fully) assess the compatibility of the EAW provisions with fundamental human rights. However, in a recent case Pl. ÚS 12/2012 (Hungarian car accident), ${ }^{56}$ two judges expressed doubt about the constitutionality of the current constitutional framework in their dissenting opinions. The facts of the case were as follows: in 2002, a Slovak citizen (Mr. J.B.) caused a car accident in Hungary. In 2004, Hungarian courts declared that Mr. J.B. was guilty of having caused a car accident that resulted in the death of a person, and requested that Mr. J.B. be surrendered to the Hungarian authorities in order to serve his sentence of imprisonment on Hungarian territory. The Slovak authorities complied with this request and surrendered Mr. J.B. to Hungary. After having served his custodial sentence in Hungary, Mr. J.B. sued the SR for damages, arguing that the legal framework that had allowed his surrender to Hungary was unconstitutional. The Slovak regional court seized of the question referred the case to the SCC, requesting constitutional review on the basis of Art. 23 of the Constitution ('freedom of movement and right of abode'). However, the SCC rejected this request on procedural grounds, since the subject matter of the pending case (i.e. Mr. J.B.'s claim for damages) was too remote from the question of constitutionality of Art. 23.

The two dissenting judges, Justice Macejková and Justice Mészáros, nonetheless expressed concerns about the constitutionality of the current legal framework, not due to the requirements flowing from the EAW itself, but rather due to the way it

\footnotetext{
${ }^{54}$ See the Explanatory Report to Act No. 154/2010 Coll., Part A (General Part).

${ }^{55}$ Ibid.

${ }^{56}$ Judgment of the SCC, Pl. ÚS 12/2012 (Hungarian car accident) of 11 July 2012.
} 
was transposed by the Slovak legislator. In the words of Justice Mészáros, 'the Slovak legislator has not used and is not using the leeway offered by the Framework Decision, which allows for a higher constitutional protection of citizens'. ${ }^{57}$ Justice Macejková furthermore stated that the legal framework would only be in conformity with constitutional requirements if the legislator decided to broaden the protection of citizens' fundamental rights and to guarantee the right to the widest extent allowed by the Framework Decision on the EAW, namely by Art. 4(6) and 5(3) thereof. This change was indeed introduced into the law, not in reaction to the dissenting opinion of Justice Macejková, but in reaction to Framework Decision 2008/909/JHA of 27 November 2008, on the application of the principle of mutual recognition to judgments in criminal matters. ${ }^{58}$ Following this EU legislative act, the NCSR adopted Act No. 549/2011 Coll., on recognition and execution of criminal decisions, and Act No. 344/2012 Coll., on changes to Acts No. 154/2010 and 549/2011 Coll.

\subsubsection{The Presumption of Innocence}

2.3.1.1 To our knowledge, no concerns have been voiced or discussed with regard to the lack of the presumption of innocence under the EAW mechanism in Slovakia. At an early stage of the Hungarian car accident case, the regional court that decided on the surrender of Mr. J.B. to Hungary merely stated that 'the judicial authority of the executing state is not entitled to examine the guilt or innocence of the person requested by the EAW, but merely to decide whether the EAW will or will not be executed'. 59 The courts thus comply with the provisions of the EAW Framework Decision, as transposed into Slovak law, which states that the executing judicial authorities are not competent to examine the question of guilt.

Moreover, it is not quite clear in the Experts' view how the presumption of innocence would specifically be undermined by a national court surrendering a person under the EAW mechanism, unless of course there is an unspoken assumption that the requesting court in another Member State is not able to conduct a fair trial. If that were the case, the key problem would rather be posed in terms of absence of fair trial or trial in a reasonable time, but not necessarily in terms of the presumption of innocence. Moreover, the fact that some persons might be deprived of their liberty for a limited time before the question of their guilt is finally determined before a judge is a general feature of any domestic legal system,

\footnotetext{
${ }^{57}$ Ibid.

${ }^{58}$ Council Framework Decision 2008/909/JHA of 27 November 2008 on the application of the principle of mutual recognition to judgments in criminal matters imposing custodial sentences or measures involving deprivation of liberty for the purpose of their enforcement in the European Union, [2008] OJ L 327/27.

${ }^{59}$ See the decision of the Regional Court in Košice, Ntc 2/04-124 (22 February 2005), as paraphrased in the Judgment of the SCC (Hungarian car accident), n. 56 above, para. 21.
} 
inherent to the institution of pre-trial custody. Also in similar, purely domestic cases, persons might be deprived of their liberty by a court order, without being immediately allowed to rebut all of the charges raised against them, which is possible only at the later full trial.

2.3.1.2 When Slovak courts are asked to surrender a person to another Member State, they do not examine the question of guilt per se. Pursuant to Act No. 154/ 2010 Coll., courts merely examine whether there are any reasons (obligatory or facultative) not to execute the EAW at stake, but they do not go beyond this analysis, since they do not have such power. The executing court is not in a position to examine the question of guilt, since that question will be examined by the foreign court that has issued the EAW. Therefore, to our knowledge, extradition has never been refused on the ground of a claim of innocence.

The procedural guarantees, including the provisions regarding the hearing of the requested person, are regulated in detail by Act No. 154/2010 Coll., which is a very loyal transposition of the EAW Framework Decision. As a result, the Slovak legal framework honours the principle of mutual trust between the EU Member States in their respective systems of criminal law. Again, under the logic of the EAW mechanism, the Slovak courts could hardly do otherwise, unless the EAW system were to revert to a traditional form of extradition proceedings as known in international law where a number of issues would be checked by the extraditing court.

Furthermore, some data have been published regarding the number of persons surrendered (a) from other states to Slovakia, and (b) from Slovakia to other states; this is summarised in Table 1.

Table 1 Data regarding surrender of persons in Slovakia

\begin{tabular}{|c|c|c|}
\hline Year & $\begin{array}{l}\text { Number of people handed over from } \\
\text { other countries to the SR }\end{array}$ & $\begin{array}{l}\text { Number of people handed over from the } \\
\text { SR to other countries }\end{array}$ \\
\hline 2008 & 116 & 36 \\
\hline 2009 & 143 & 53 \\
\hline 2010 & 152 & 48 \\
\hline 2011 & 170 & 65 \\
\hline 2012 & 157 & 45 \\
\hline 2013 & 140 & 47 \\
\hline 2014 & 143 & 58 \\
\hline
\end{tabular}

Source The Slovak Ministry of Interior. [See the statistics of the Slovak Ministry of Interior. http:// www.minv.sk/?European_Arrest_Warrant]

\subsubsection{Nullum crimen, nulla poena sine lege}

2.3.2.1 The abolition of dual criminality has not been addressed by the Slovak courts. Technically, the principle of nulla poena sine lege is not breached, since the legal framework incorporates the EAW as a legal instrument into the legal order, 
and it is thus foreseeable for citizens that in certain cases, they can be prosecuted for crimes that are (only) punishable in Member States other than the SR.

By way of constitutional provisions, Art. 17 of the Constitution states: '(1) Personal freedom is guaranteed. (2) No one may be prosecuted or deprived of freedom other than for reasons and in a manner which shall be laid down by law', and Art. 49 states: 'Only the law establishes which conduct constitutes a criminal act and what punishment or other form of deprivation of rights or property may be inflicted upon those who commit it.' Since the provisions of the EAW Framework Decision have been properly implemented, they have become part of the Slovak legal framework.

Still, concerns have been expressed by academic experts. Jakubčík has claimed that Art. 2(2) of the EAW Framework Decision is 'the most controversial point of the law on the EAW', since it brings about 'severe procedural consequences for Slovak judicial authorities'. ${ }^{60}$ He considers the 32 categories to be too vaguely formulated and too broad, which results in the incorrect classification of crimes by the Member States, or even abuse of the vagueness by the Member States. ${ }^{61}$ However, apart from the occasional academic voices, the issues outlined above have not, to our knowledge, given rise to any (constitutional) litigation.

\subsubsection{Fair Trial and In Absentia Judgments}

2.3.3.1 In contrast to the Spanish constitutional system but similarly to a number of other legal systems including the Czech legal system, the Slovak legal order does not perceive in absentia judgments as a constitutional problem. Articles 358-362 of the Code of Criminal Procedure (Act No 301/2005 Coll.) provide for a specific type of criminal procedure entitled 'proceedings against a fugitive'. This type of procedure will be triggered against an accused person who evades criminal proceedings by escaping abroad or by hiding. The fugitive is assigned an attorney, who will represent the fugitive throughout the entire procedure. Article 361(1) of the Code of Criminal Procedure expressly provides that the announcement of the date and place of the trial will be made public and will be served to the appointed attorney. The trial will, however, take place irrespective of whether or not the accused has obtained knowledge of it. Finally, Art. 362(2) opens the possibility of a retrial once the accused obtains knowledge of either the trial or the final sentence, made subject to two types of time limits: a subjective one, i.e. six months from the moment the accused obtained knowledge of the trial/sentence, and an objective one, referring to the general provisions on prescription for the individual crime provided for in the Code of Criminal Procedure.

Thus, re-trial is conceived as a matter or right, open to the accused, typically if the accused returns to the national territory. It does not, however, appear to be a

\footnotetext{
${ }^{60}$ See Jakubčík 2009, pp. 1178-1188.

${ }^{61}$ Ibid.
} 
constitutional requirement. As a consequence, in absentia judgments and their execution under the EAW mechanism are constitutionally possible. To our knowledge, their constitutionality has not been challenged. Even if it were, it is hard to see how the SCC could find such practice unconstitutional. After all, it is the fugitive who by his absence or hiding obstructs the course of justice, and there is the possibility of a re-trial should the fugitive return to the national territory.

\subsubsection{The Right to a Fair Trial - Practical Challenges Regarding a Trial Abroad}

2.3.4.1 As to the issue of providing assistance to extradited citizens or residents, there are two different scenarios that arise from this question. First, legal aid provided by the surrendering Member State to the person it is surrendering, but before any trial takes place in the requesting Member State. Second, ex post facto help to persons who have been extradited but subsequently acquitted in the requesting Member State or subjected to extensively long proceedings or a miscarriage of justice.

As far as the first scenario is concerned, pursuant to Decree No. 135/1994 Coll., on the expatriation of persons, the SR bears some of the costs. Article 8 of this Decree states the following:

(1) Costs incurred by the surrendering of the sentenced person, who is in detention or who is serving their imprisonment sentence, to the competent body of the Police forces, are borne by the Prison Service of the Slovak Republic.

(2) Personal expenses and travel expenses incurred by the expatriation are borne by the sentenced person alone, unless another natural or legal person decides to bear them.

(3) If the sentenced person does not have their own financial means to cover the costs of the expatriation sentence, these are borne by the Police forces.

There appear, however, to be no dedicated national funds for assisting surrendered persons in other Member States. This is perhaps not entirely surprising, since under the logic of the EAW mechanism, the surrendered individual should be allowed to make use of the local system of legal aid in the state to which he or she is surrendered.

The same logic applies to the second scenario. Under Slovak law, damages can be claimed from the Slovak state for unlawful detention, excessively long proceedings or other miscarriages of justice. ${ }^{62}$ However, such damages must be

\footnotetext{
${ }^{62}$ See Art. 46(3) of the Constitution: 'Everyone is entitled to compensation for damage incurred as a result of an unlawful decision by a court, or another state or public administration body, or as a result of an incorrect official procedure.' This constitutional provision is further implemented in Act No. 514/2003 Coll. on the liability for damage caused by the exercise of public power, which regulates the conditions of compensation in cases of unlawful decisions, unlawful limitations of personal freedom, unlawful sanctions or incorrect administrative proceedings. Although the
} 
attributable to a failure on the part of the Slovak (judicial) authorities. ${ }^{63}$ The rationale behind the right to compensation has been clarified by the Supreme Court of the SR:

\begin{abstract}
If a state is to be truly rooted in the rule of law principle, it must bear objective liability for the conduct of its authorities that have directly interfered with the fundamental rights of an individual .... On the one hand, prosecuting authorities are obliged to prosecute and sanction criminal activities, but on the other hand, the state cannot avoid liability for the conduct of such authorities if such conduct turns out to be mistaken, interfering with fundamental rights. In such a situation, the important issue is not how the authorities have assessed the original accusation, but whether their presumptions were confirmed in the criminal proceedings. ${ }^{64}$
\end{abstract}

On the other hand, a person who has been surrendered to Slovakia from another Member State under the EAW mechanism and who has been exposed to any of the above-mentioned miscarriages committed by Slovak authorities could claim damages under this heading.

As for any institutionalised assistance to individuals involved in trials abroad, there is a difference between what would be desired and what would be legally and economically possible. With regard to individual fates and situations, some form of financial support could only be commended. Structurally, however, it would be difficult to put into practice unless the 'publicly funded' assistance were adopted on the European level, with equal support for all European citizens. Only in this way could equality amongst EU citizens be guaranteed; if states were to reserve such aid only for their citizens (or previous residents) abroad, it would be likely that the aid would quickly bring about a 'caste system' in access to justice based on de facto nationality, amounting to a textbook example of indirect discrimination on the grounds of nationality. Imagine that a Czech and a Swedish citizen were surrendered under the EAW system to, for example, Greece, but only Sweden provided financial assistance to its citizens standing trial abroad. Both of them would be sent to an 'unknown environment' in which they arguably need assistance. Thus, their situation could be said to be in all material aspects comparable. But since only one Member State provided assistance, both 'European citizens' could be treated very differently. Furthermore, introduction of such state-based measures could also be understood as the re-introduction of traditional public international law features into EU law, whereby states would exercise a sort of 'diplomatic protection' over their citizens on the territory of other Member States, in the form and extent known in general public international law.

2.3.4.2 There are no comprehensive statistics capturing the proportion of unfounded extraditions, but once in a while, the media points out an individual story involving

\footnotetext{
situation of an acquittal is not explicitly covered by the Act, courts have concluded by means of analogous interpretation that such situations also fall within the scope of the Act (see Judgment of the Supreme Court of the SR, No. 3 Cdo 194/2010).

${ }^{63}$ Cf. Art. 3(1) of Act No. 514/2003 Coll.

${ }^{64}$ See Decision of the Supreme Court of the SR, No. 4 M Cdo 15/2009.
} 
judicial error. One recent case concerned a Slovak national who was extradited to the Netherlands under the provisions of the EAW, but was later acquitted because it became evident that the DNA samples had been mixed up and that the accused was in fact innocent. Mr. Harabin, the former president of the Supreme Court of the SR, has recently suggested that such cases are not rare and that it is necessary to initiate a legislative solution that would help minimise judicial errors and compensate innocent citizens who have suffered damage. ${ }^{65}$ However, as already noted, no reliable data in this regard is available.

\subsubsection{The Right to Effective Judicial Protection: The Principle of Mutual Recognition in EU Criminal Law and Abolition of the Exequatur in Civil and Commercial Matters}

2.3.5.1 After the Slovak accession to the EU, a number of mutual recognition issues arose in civil, administrative and criminal matters. For administrative matters, the cases were similar to those described in the question ${ }^{66}$ and were in fact raised in a Czech request for a preliminary ruling in Kyrian ${ }^{67}$ before the Court of Justice. The Kyrian case concerned the enforcement of an order for payment of excise duty owed by Mr. Kyrian, a Czech truck driver, to German customs authorities (Hauptzollamt Weiden) for amounts of imported alcohol. After the Czech accession to the EU in 2004, the German authorities served the order for payment on Mr. Kyrian through the Czech tax authorities pursuant to Art. 6 of Directive 76/308. ${ }^{68}$ The case gave rise to two important questions of principle: the permissible scope of review of the administrative order for payment by the courts of the executing state and the question of the language in which the order was to be served. The element common to both questions was the problem of effective legal protection for decisions crossing

\footnotetext{
${ }^{65}$ See the media coverage of this story: (2013, July 10). Šefan Harabin navrhuje upravit' európsky zatýkací rozkaz (Štefan Harabin suggests amending the European Arrest Warrant). Webnoviny.sk. http://www.webnoviny.sk/slovensko/clanok/700381-stefan-harabin-navrhuje-upravit-europskyzatykaci-rozkaz/.

${ }^{66}$ Generally, however, tax and customs decisions from other Member States would be enforced under the heading of cooperation in administrative matters, and not as a civil matter, as would appear to be indicated by the Estonian case. For an exception confirming the rule, see ECJ, Case C-49/12 Sunico and Others [2013] ECLI:EU:C:2013:545.

${ }^{67}$ Case C-233/08 Kyrian [2010] ECR I-00177.

${ }^{68}$ Council Directive 76/308/EEC of 15 March 1976 on mutual assistance for the recovery of claims resulting from operations forming part of the system of financing the European Agricultural Guidance and Guarantee Fund, and of the agricultural levies and customs duties, [1976] OJ L 73/ 18, in the meantime replaced by Council Directive 2008/55/EC of 26 May 2008 on mutual assistance for the recovery of claims relating to certain levies, duties, taxes and other measures, [2008] OJ L 150/28, which was itself soon repealed by Council Directive 2010/24/EU of 16 March 2010 concerning mutual assistance for the recovery of claims relating to taxes, duties and other measures, [2010] OJ L 84/1.
} 
borders between Member States: how far (if at all) may the executing Member State subject the administrative order coming from a different state to any substantive judicial review, in particular if because of a lack of knowledge, the individual did not seek judicial review in the requesting state? Moreover, in what language must the order for payment be served?

In Kyrian, the opposing approaches of the Advocate General and the Court itself are noteworthy. In his Opinion, AG Mazák robustly relied on effet utile and a purposive reading of the Directive: full effectiveness of horizontal mutual assistance for the recovery of levies and taxes cannot be called in question and must be asserted, even if the procedural system established by the Directive is rather questionable and leaves the individual without any possibility of judicial review of an administrative decision in the adoption of which he did not participate in the requesting state and which was simply served on him in his home state in a foreign language. Conversely, the Court (first chamber) took a much more critical and rights-protective approach to the interpretation of the Directive: the courts of the executing Member States are entitled to carry out (albeit limited) judicial review and the individual must be served with documents in the language of the executing Member States, i.e. in a vast number of cases, his own language.

In general, however, broader concerns of the sort outlined in the question cannot be detected in either Slovak case law or commentary. It cannot, however, be stated categorically that effective legal protection is no longer guaranteed following the introduction of cooperation in criminal, administrative and civil matters. Such assessment will be very case-dependent and cannot be stated in such categorical terms.

Perhaps the best approach in cases like that of Mr. Kyrian would be to open up the possibility of an administrative court retrial and/or extraordinary administrative review in the requesting Member State within the normally applicable time-limits, conditional upon the fact that the addressee of the original administrative act had no knowledge of the administrative proceedings against him being carried out in the requesting Member State. The burden of proof would be on the authorities of the requesting Member State that would have to establish that at a certain point in time, the addressee of the act was duly served (as would normally be the case with truck drivers involved in smuggling at the moment of the interception of the goods by the customs authorities).

2.3.5.2 In Slovak scholarship, there is no discernible debate about the suitability of transposing mutual recognition from internal market matters to criminal law and civil and commercial disputes. However, to state that the principle of mutual recognition cannot be transposed per se from the area of internal market to criminal, civil or administrative matters is again not warranted in such categorical terms. The debate should rather be conducted about the exact procedural modalities, scope and possible exceptions. After all, mutual recognition is not a principle unique to EU law. International cooperation writ large in criminal or civil matters is based on the same principle, albeit in a more limited form. 
2.3.5.3 There has been no debate regarding a change in the role of the courts.

2.3.5.4 As already outlined above, Act No. 154/2010 Coll. (implementing the EAW Framework Decision), introduced a proportionality clause in its Art. 5(3) (see Sect. 2.3 above). However, this 'check' applies only if a Slovak court is the requesting court, i.e. for considerations whether or not an EAW shall be issued. It also has no bearing on the issue of guilt.

On a general level, re-introducing judicial review in the surrendering Member State prior to the surrender would essentially amount to returning to traditional extradition proceedings. The same applies to the potential re-insertion (or rather re-evaluation, since it still remains in some residual form in Regulation 44/2001) ${ }^{69}$ of exequatur for civil and commercial matters. Should such (essentially political) decision be taken, EU legislation in these areas would become unnecessary.

\subsection{The EU Data Retention Directive}

2.4.1 The Data Retention Directive ${ }^{70}$ was implemented in the Slovak legal order by inserting new provisions into a number of legal acts, most notably Act No. 351/ 2011 Coll., on electronic communications and Act No. 301/2005 Coll., the Code of Criminal Procedure. The Slovak legislator opted for a rather modest implementation: internet data are to be retained for 6 months and all other data for 12 months.

This implementing legislation was challenged in October 2012 by a group of 31 MPs in a petition for abstract constitutional review pursuant to Art. 125(1)(a) of the Constitution. The claimants argued that the provisions were in breach of a number of provisions of the Slovak Constitution, ${ }^{71}$ as well as Arts. 8 and 10 of the European

\footnotetext{
${ }^{69}$ Council Regulation (EC) No 44/2001 of 22 December 2000 on jurisdiction and the recognition and enforcement of judgments in civil and commercial matters, [2001] OJ L 12/1.

${ }^{70}$ Directive 2006/24/EC of the European Parliament and of the Council of 15 March 2006 on the retention of data generated or processed in connection with the provision of publicly available electronic communications services or of public communications networks and amending Directive 2002/58/EC, [2006] OJ L 105/54.

71 The allegedly violated provisions were the following: 'Article 13: ...
}

(4) When restricting constitutional rights and liberties, attention must be paid to their essence and meaning. These restrictions must not be used for any other than the set purpose.

Article 16: (1) The inviolability of the person and its privacy is guaranteed. It can be limited only in cases defined by law.

$\ldots$

Article 19: ...

(2) Everyone has the right to protection against unwarranted interference in his private and family life. (3) Everyone has the right to protection against the unwarranted collection, publication, or other illicit use of his personal data. 
Convention on Human Rights (ECHR), and Arts. 7, 8, 11 and 52(1) of the EU Charter.

According to the claimants, the collection of data amounted to universal surveillance of all citizens, irrespective of their integrity and (lack of) criminal record. The claimants invoked a number of European Court of Human Rights cases, such as Klaas v. Germany ${ }^{72}$ and Copland v. UK, ${ }^{73}$ arguing that the data collection and retention amounted to a significant interference in the private life of individuals. They acknowledged that the interference pursued a legitimate aim, namely the protection of national security, national defence and public security, but they disagreed with the appropriateness of the adopted measures and their necessity. Moreover, the claimants argued that the challenged measures denied the very nature of the right to privacy. With regard to the EU dimension of the discussion, the claimants requested the SCC to submit a reference for a preliminary ruling to the Court of Justice. ${ }^{74}$

The SCC was aware of the pending case in Digital Rights Ireland, and the judges decided to wait for the outcome of that case, rather than to refer their own question to the Court of Justice. In April 2014, when the judgment in Digital Rights Ireland was published, ${ }^{75}$ the SCC issued an interim decision ${ }^{76}$ suspending the legal effects of the challenged legal provisions until the publication of the final decision in the case.

The decision on merits was delivered one year later, on 29 April 2015. The SCC opened its analysis by discussing the referential framework of constitutional review, acknowledging that

[e]ven after the accession of the SR to the EU, the referential framework of constitutional review remains limited to the norms of the Slovak constitutional order. However, the Constitutional Court cannot disregard the effects of EU law on the creation, application and interpretation of domestic norms in the fields of regulation that have their origin in EU law. ${ }^{77}$

Article 22: (1) The privacy of correspondence and secrecy of mailed messages and other written documents and the protection of personal data are guaranteed. (2) No one must violate the privacy of correspondence and the secrecy of other written documents and records, whether they are kept in privacy or sent by mail or in another way, with the exception of cases to be set out in a law. Equally guaranteed is the secrecy of messages conveyed by telephone, telegraph, or other similar means.

...

Article 26: (1) The freedom of speech and the right to information are guaranteed.'

${ }^{72}$ Klaas v. Germany, 22 September 1993, Series A no. 269.

${ }^{73}$ Copland v. the United Kingdom, no. 62617/00, ECHR 2007-I.

${ }^{74}$ See the claimants' submissions in Part I of the SCC judgment in case Pl. ÚS 10/14, n. 14 above, pp. 2-27.

75 Joined cases C-293/12 and C-594/12 Digital Rights Ireland and Seitlinger and Others [2014] EU:C:2014:238.

${ }^{76}$ Decision of the SCC, Pl. ÚS 10/14-29 (Data retention, interim) of 23 April 2014.

${ }^{77}$ See Pl. ÚS 10/14 (Data retention), n. 14, para. 62. 
The SCC then elaborated on the principles of the scope of application of EU law, referring to Art. 51(1) of the EU Charter and the explanatory notes thereto, as well as to the judgments of the Court of Justice in a number of cases (i.e. Wachauf, ${ }^{78}$ ERT, ${ }^{79}$ Fransson $^{80}{ }^{\text {Ymeraga }^{81}}$ and Siragusa ${ }^{82}$ ). On the basis of this case law, the SCC concluded that even after the annulment of the Data Retention Directive, the domestic implementation thereof is still to be seen as a measure adopted within the scope of application of EU law, since it represents a derogation from the E-Privacy Directive ${ }^{83}$ namely Art. 15(1) thereof. ${ }^{84}$ The SCC therefore concluded that in the constitutional review of the challenged decisions ... the Constitutional Court must also take into consideration the relevant provisions of the Charter, especially Art. 7, 8, and 52(1) thereof and the relevant case law of the Court of Justice of the EU' ${ }^{85}$ However, in its ruling, the SCC declared that the implementation measures were in breach of several provisions of the Slovak Constitution, namely Arts. 13(4), 16(1), 19(2), 19(3) and 22, as well as Art. 8 ECHR, without addressing the alleged breach of the Charter provisions.

The decision of the Court of Justice in Ireland $v$. Council ${ }^{86}$ was not addressed at all by the SCC.

It can be only the purest speculation what the decision of the SCC or the SSC might have been if the case had been approached as an issue of national constitutional review only, without the constraints and guidance from the Court of Justice. However, as far as such speculation might be offered, it is more likely that if it were to face a purely national measure of a similar kind, the SCC, similarly to other constitutional courts in the Central European region, would be rather likely to annul such similar measure as unconstitutional.

The reason for such an outcome in balancing these values might be traced back to historical experience. In this regard, a number of new, Central and Eastern European Member States, but also Germany and Austria, highly value the right to privacy, in particular in its dimension as the prohibition of large-scale, systemic governmental 'spying' on a state's own citizens. ${ }^{87}$ The robust German constitutional case law

\footnotetext{
${ }^{78}$ Case 5/88 Hubert Wachauf v. Bundesamt für Ernahrung und Forstwirtschaft [1989] ECR 02609.

${ }^{79}$ Case C-260/89 ERT [1991] ECR I-02925.

${ }^{80}$ Case C-617/10 Akerberg Fransson [2013] ECLI:EU:C:2013:105.

${ }^{81}$ Case C-87/12 Ymeraga and Ymeraga-Tafarshiku [2013] EU:C:2013:291.

${ }^{82}$ Case C-206/13 Siragusa [2014] EU:C:2014:126.

${ }^{83}$ Directive 2002/58/EC of the European Parliament and of the Council of 12 July 2002 concerning the processing of personal data and the protection of privacy in the electronic communications sector, [2002] OJ L 201/37.

${ }^{84}$ See Pl. ÚS 10/14 (Data retention), n. 14, para. 68.

${ }^{85}$ Ibid.

${ }^{86}$ Case C-301/06 Ireland v. European Parliament and Council [2009] ECR I-00593.

${ }^{87}$ As indirectly also confirmed by the list of the Member States that eventually ended up invalidating parts of the national measures implementing the Data Retention Directive, before as well as after the decision of the Court of Justice was rendered.
} 
concerned with the right to 'informational self-determination" ${ }^{88}$ might be seen as providing the intellectual leadership in this area, followed in a number of the new Member States. The historical explanation for such enhanced protection of the private sphere is not difficult to understand. The reality of total surveillance by the secret police in the East before 1989 can perhaps be best explained visually, by simply watching, for instance, the film 'The Lives of Others' ${ }^{89}$

Thus, if any advised guess might be entered, then the SCC, together with other constitutional courts in the region, would be more likely to react rather sensitively to a blanket, arguably disproportionate surveillance of citizens, and more likely to annul such measures if they originated from the national level only.

\subsection{Unpublished or Secret Legislation}

2.5.1 Article 1 of the Act No. 416/2004 Coll., on the Official Journal of the EU, provides that only legally binding measures of the Union that have been published in the Official Journal of the EU may produce effects on the territory of the SR. Moreover, the SCC has also ruled that as a matter of general principle, laws cannot enter into effect before their publication in the Official Journal of the SR. ${ }^{90}$

The absence of the due publication of secondary EU law after the 2004 accession $^{91}$ was recognised as a pressing problem and discussed in the Slovak scholarship. ${ }^{92}$ However, the first court cases apparently came only after the decision of the Court of Justice in Skoma-Lux. ${ }^{93}$ Thus, for example, in a decision of 18 March 2008, case No. 5 Sžf 59/2007, the Slovak Supreme Court applied the holding of the Court of Justice from Skoma-Lux to a case concerning the importation of a quantity of industrial salt from Ukraine and Belarus. The Supreme Court observed that at the time at which the contested importation took place, the Commission Regulation implementing the Common Customs Tariff was not available in Slovak, and annulled the decision of the customs authorities.

In contrast, there have been no cases concerning the (total) absence of publication of statutes (legislation), such as those that arose in the Heinrich case. ${ }^{94}$ Under

\footnotetext{
${ }^{88}$ Starting already with BVerfGE 65, 1 (Volkszählung), judgment of the First Chamber of the Federal Constitutional Court of 15 December 1983, 1 BvR 209/83, resounding in the judgment of 2 March 2010, 1 BvR 256/08, 1 BvR 263/08, 1 BvR 586/08 that declared the German legislation transposing the Data Retention Directive unconstitutional.

${ }^{89}$ Original title 'Das Leben der Anderen', director Florian Henckel von Donnersmarck, release date 13 April 2007. The film depicts the surveillance measures, phone tapping and flat bugging by the East German secret State Police (Stasi) in East Berlin in the 1980s.

${ }^{90}$ See Judgment of the SCC, PL. ÚS $17 / 96$ (Publicity of laws) of 4 March 1998.

${ }^{91}$ Further e.g. Bobek 2006-2007.

92 Hodás 2008 or Procházka 2004, p. 856.

${ }^{93}$ Case C-161/06 Skoma-Lux [2007] ECR I-10841.

${ }^{94}$ Case C-345/06 Heinrich [2009] ECR I-01659.
} 
the Slovak constitutional understanding outlined above (Sect. 2.1.3), the due publication of a statute would be seen as a necessary condition for its validity. If a statute has never been published, it has never came into existence as a valid piece of legislation. Thus, under Slovak constitutional rules, the total absence of publication of a legally binding act would entail the nullity of the act in question, i.e. it would be declared to be legally non-existent. That means that secret statutes (Acts of Parliament) cannot exist, because the legislative process would not be complete without a due publication of the statute.

By the way of a conclusion, it might be added that neither the Polish nor the Czech courts were obliged to 'revisit their more stringent' decisions for the simple reason that the result of the case would have been the same. What was typically attacked was the decision of a national administrative authority whereby the latter imposed a sanction or a fine based on EU legislation, which was not available in the official language of the Member State in question at the material time in question. Under Czech, Polish and Slovak law, such an administrative decision had to be annulled, because it was, formally speaking, issued without a legal basis (non-existent legislation). In its Skoma-Lux decision, the Court of Justice stated that such EU legislation is valid, but it cannot impose obligation on individuals. Thus, applying Skoma-Lux in the pending national cases also meant the compulsory annulment of the national administrative decisions. Therefore, although the underlying theoretical construction was different, the practical effect of both approaches amounted to the annulment of the original national administrative decision. For this reason, and also due to the fact that the Court of Justice expressly limited the temporal effects of the Skoma-Lux decision to pending cases, ${ }^{95}$ the national courts with the originally more 'stringent' approach have not in fact been obliged to revisit anything. ${ }^{96}$

\subsection{Rights and General Principles of Law in the Context of Market Regulation: Property Rights, Legal Certainty, Non-Retroactivity and Proportionality}

2.6.1 There have been no such debates in the Slovak context.

\footnotetext{
95 Case C-161/06 Skoma-Lux, n. 93 above, para. 72.

${ }^{96}$ Further on the Skoma-Lux aftermath, see Bobek 2016.
} 


\subsection{The ESM Treaty, Austerity Programmes and the Democratic, Rule-of-Law-Based State}

2.7.1 The Treaty Establishing the European Stability Mechanism (ESM Treaty) and other proposed measures of financial solidarity across the eurozone have raised considerable discussion in the Slovak media, but have never been dealt with by the Slovak courts. The ESM was introduced into the Slovak legal order by Act No. 296/2012 Coll., on the European Stability Mechanism, which governs some of the rights and obligations of the SR in the ESM. The overall contribution of the SR amounts to 5.768 billion EUR, of which 659 million EUR is the paid-in capital, while the remaining amount of 5.109 billion EUR is the unpaid capital subscription. In 2012, the GDP of the Slovak Republic was 72.185 billion EUR, which means that the amount of the ESM paid-in capital equals $0.91 \%$ of the GDP, while the full ESM capital subscription of Slovakia represents about $8 \%$ of its GDP.

2.7.2 There has been no separate debate about the other proposed measures; the Slovak media usually treats these systems as one single topic of 'financial solidarity in the eurozone'. In the public debates, the issues of transparency and democratic control were discussed in the context of the potential (Greek) sovereign default and the duty of Slovakia, as a Member of the eurozone, to contribute to yet another bailout programme for Greece. It was generally suggested that Slovakia, as a poorer Member State with nominal income per capita in fact lower than in Greece and as a state that itself was obliged to introduce harsh reform measures in the early 2000s, should not be asked to guarantee the public debts of a country that is in fact better off, but apparently not ready or able to carry out any reforms.

Thus, if Slovakia were really obliged to pay up at a certain stage, constitutional or legal dispute from the other side would be more conceivable than those described with regard to the recipient side, namely citizens or other subjects challenging the uncontrolled and thus undemocratic public spending of the Slovak authorities to pay someone else's debts abroad.

It is also interesting to note that in response to the Slovak participation in the ESM Treaty, the Government of Prime Minister Radičová lost a confidence vote and was brought down.

2.7.3 Not applicable, since Slovakia has not been the subject to a bail-out programme.

\subsection{Judicial Review of EU Measures: Access to Justice and the Standard of Review}

2.8.1 Since the pleadings of the parties are not accessible to the public, it is impossible to state in how many cases individuals have requested a Slovak court to submit a request for a preliminary ruling concerning the validity of an EU measure. 
What is, however, known is that Slovak courts have not yet submitted any preliminary ruling references with regard to the validity of an EU measure.

2.8.2 There is no representative debate discernible on the standard of judicial review by the CJEU in Slovakia.

2.8.3 As for the approach of the Slovak courts to the review of constitutionality/ legality of legislation, no comprehensible statistical data exist in this regard. In general, it could be suggested that the SCC, in particular in the first Constitutional Court (1990s), as well as the early second Court (early 2000s), was quite an assertive court, exercising rigorous constitutional review. This would have led to a higher portion of annulments, both of general legislation as well as executive acts.

However, such findings have to be put into their proper context. First, Central and Eastern European constitutional courts, put in place in early 1990s as the guardians and enforcers of the new constitutional settlement, ${ }^{97}$ in general demonstrated a higher rate of reversals than their Western counterparts. ${ }^{98}$ This was logical since a substantial part of their work was to weed out the old 'Communist' legislation, practices and acts, which still remained in force but were no longer compatible with a democratic, rule-of-law-based state. Secondly, this already enhanced level of annulments was supplemented by the peculiar context of the Slovak political landscape of the second half of 1990s and early 2000s, in which the SCC played the occasional role of the residual guardian of the democratic legal order against the autocratic tendencies of the Mečiar-led Government. ${ }^{99}$

For these reasons, the perhaps statistically higher rate or reversals/annulments carried out by the constitutional courts in the newly emerged CEE democracies in the 1990s up to perhaps the mid-2000s, cannot really be compared with the reversal rate prevailing in the established systems in the West, or with the EU system. Both of these are established systems, in which one would normally assume the reversal/ annulment rate to be rather low, since the normal (non-transitory) political and legal mechanisms ought to operate properly.

2.8.4 As has already been outlined in the replies to the previous questions, the constitutional review carried out by the SCC with regard to EU law has so far been notably 'light touch' and quite deferential. In general terms, the SCC has accepted a variety of the Solange construction, and has effectively withdrawn its review from the area of competences transferred to the European level.

The decision of the SCC in case II. ÚS 501/2010 ${ }^{100}$ might provide an illustration in this regard. The case concerned a decision of the European Commission that declared a previous tax relief granted to a company as state aid incompatible with the internal market. The recipient of the state aid contested the internal binding force of the Commission's decision, suggesting that national courts cannot be

\footnotetext{
${ }^{97}$ In detail Bobek 2013a, pp. 255-272.

${ }^{98}$ For a Visegrad comparison regarding the 1990s, including some figures, see Procházka 2002.

${ }^{99}$ For a personal retrospective, see Drgonec 2010.

${ }^{100}$ Judgment of the SCC, II. ÚS 501/2010 (Tax relief) of 6 April 2011.
} 
bound by a mere administrative decision of a European institution. If they were, it would amount to the negation of the requirement of an independent judicial review and protection.

In dismissing such suggestions, the SCC noted that on the European level, judicial legal protection is guaranteed by the Union courts, which are entitled to review an administrative decision of the Commission. Expressly referring to the decision of the German Federal Constitutional Court in Solange II, ${ }^{101}$ the SCC concluded that it also accepts the control exercised by the Union courts with regard to the exercise of the competences transferred to the Union, and has generally no reason to consider it insufficient.

2.8.5 If such lower level standard of protection on the European level were to be ascertained, then a gap in judicial protection might indeed pose a problem. So far, it has not, however, been identified and discussed as such in the Slovak scholarship or case law. The rather sporadic and occasional dissonant voices direct themselves more towards the national legislator who, when transposing EU law and fleshing it out in the Slovak legal order, have not made full use of the leeway and discretion attributed to it by the Union legislator, such as was the case with the first domestic implementation of the EAW Framework Decision (discussed above in Sect. 2.3).

2.8.6 No discussion regarding equality of treatment of individuals within and outside the scope of national/EU law has arisen in Slovakia with regard to this issue.

\subsection{Other Constitutional Rights and Principles}

2.9.1 With regard to a shift in implementation of EU measures from parliamentary legislation to governmental regulation, see Sects. 1.4.1 and 2.1.3.

\subsection{Common Constitutional Traditions}

2.10.1 The fact that a question framed in such a way in the FIDE 2012 Congress questionnaire stirred little enthusiasm in terms of national rapporteurs answering it might be explained in two ways. First, national experts and national rapporteurs are normally called to provide information and assessment with regard to the one Member State for which they are providing a report. Thus, if asked, a rapporteur might provide an opinion whether or not, for example, the principle 'nulla poena sine lege' forms a part of the national legal system. The rapporteur cannot, however, without the knowledge of the state of law of a sizeable number of other Member

10119 BVerfGE 73, 339 [1986] (Solange II). 
States, answer the question whether or not the same principle might be a common European constitutional tradition.

Thus, nulla poena sine lege or the right to judicial protection may certainly be viewed as general principles of law recognised in the Slovak constitutional system. Whether they might be elevated to the 'European' level in this regard and proclaimed to also be common European constitutional traditions is for the general rapporteur, having an overview of the situation in a number of Member States, to ascertain.

Secondly, however, the identification of general principles of law in the European legal space remains an exercise in 'value comparison'. ${ }^{102}$ This means that establishing a new general principle in law is not a matter of mere 'head counting', in which it would be ascertained which is the most common solution with this then automatically accepted. It is an exercise in value congruence and approximation, seeking to find out which of the possible solutions match not only in terms of function, but also in terms of values and convictions. Thus, the fact that a majority of Member States adopts a solution X does not necessarily mean that the EU or the ECHR system must also adopt solution $X .^{103}$

2.10.2 To our knowledge, the 'common constitutional traditions' might play a greater role in EU law already today than visible from the outside. First, a number of national courts, when submitting a request for a preliminary ruling, already in fact make a reference to their national context/legal and constitutional situation and explain why this or that principle of EU law in question is of importance to them. In this way, they draw the attention of the Court of Justice to the existence of their national approach and tradition, often, however, with too much emphasis on the national aspect, rather than what is 'common' across the EU. ${ }^{104}$ Secondly, when deciding more important cases, the Court of Justice's Research and Documentation Service draws up comparative reports on issues commissioned by members of the Court, often dozens every year.

The idea that the reference to comparative materials ought to be 'delegated' to the national courts posing the question is both unrealistic and dangerous. It is unrealistic in the sense that it is difficult to expect 'mortal' judges to, in addition to all the work they have already got on their plate, carry out a Comparative Study of the question they are about to ask, drawing also on legislation and case law from other systems in the EU. It is equally dangerous because if such a requirement were

\footnotetext{
102 Already in Zweigert 1949, who called it 'wertende Rechtsvergleichung'.

${ }^{103}$ Further on the various ways of using comparative inspiration in EU law, see e.g. Lenaerts 2003 or Kiikeri 2001.

${ }^{104}$ For example, in the Heinrich case discussed above, the submitting Verwaltungssenat im Lande Niederösterreich clearly pointed out that under Austrian (and German) law, the absence of due publication is an issue of validity, not mere interpretation. The referring court also in fact posed its question as a request for a preliminary ruling on validity, not on interpretation. It was the Court of Justice which rephrased the question; but it was certainly aware of the German approach and tradition, which was also discussed in quite some detail by AG Sharpston in her Opinion in Case C-345/06 Heinrich [2009] ECR I-01659.
} 
to be set, it is likely that very few national judges would be inclined to send any more references. By way of a parallel, the Court of Justice has famously stated in CILFIT $^{105}$ that a Comparative Study of the approaches adopted by other Member States' highest courts is to be carried out in order to ascertain that the answer is 'equally obvious' to them and therefore there is no need for a preliminary ruling. It is perhaps also no secret that this requirement of the Court of Justice has remained a dead letter. In sum, if anybody should carry out comparative studies and draw the attention of the legal practice to the existence of or a need for a 'common constitutional tradition', it should be the legal scholarship, but hardly the judges.

\subsection{Article 53 of the Charter and the Issue of Stricter Constitutional Standards}

2.11.1 As already explained in the Introductory Note to this report and occasionally reiterated with regard to rather specific and advanced doctrinal issues in EU law, such issues are not really the 'daily bread' in small jurisdictions.

\subsection{Democratic Debate on Constitutional Rights and Values}

2.12.1 Since at the time of the adoption of the EAW FD Slovakia was not yet a Member State of the Union and, at the moment of the adoption of the EU Data Retention Directive, it had just become a Member State, no public debate can be discerned on these issues at the time in question. This might not necessarily mean, however, that information on these pieces of legislation was withheld or kept secret from the public, but rather that in the avalanche of the pre-accession EU acquis that had to be transposed, nobody really noticed.

2.12.2 Perhaps a more useful question might be when should the 'system' allow sufficient space for democratic deliberation, since the answer to the question if there should be more democratic deliberation is bound to always be 'yes'. From the point of view of the EU legislator, the requirement that democratic deliberation and accommodation of important constitutional issues ought to be carried out before the adoption of an act of EU law is perhaps not that surprising. In other words and for the purpose of a potential infringement action brought by the European Commission against a defaulting Member State, the suggestion that that state should have either voiced its concerns within the EU legislative process and sought the appropriate blocking minority to prevent the adoption of the measure and/or, if

${ }^{105}$ Case 283/81 CILFIT v. Ministero della Sanità [1982] ECR 03415, para. 16. 
outvoted, challenged the measure before the Court of Justice, does not seem misplaced if viewed from the EU perspective. The issue of standing does not really come into play here, because a Member State is always a privileged applicant (of course if remaining within the time limits).

What might rather pose a problem, in practical terms, is when there is no one single position on an EU law issue within a Member State: the legislature might have different ideas than the executive, which in turn might think something quite different than the courts and/or the national constitutional court. The recent cases of Landtová $^{106}$ and Holubec ${ }^{107}$ demonstrate the unlucky constellation in which the absence of a voice on the European level might prod a national actor into an open revolt. $^{108}$

A different question is whether the EU legislative process allows for a sufficient scope of deliberation before a measure is adopted. In general, and in particular since the Treaty of Lisbon, the potential for participation of both the national governments as well as the national parliaments is perhaps not that bad as sometimes portrayed. A separate issue is, rather, to what degree the national players really make use of the space provided to them. The pragmatic record here might not be that optimistic: national governments sometime agree a measure in Brussels but then negate it politically when it is met with a hostile reception in their domestic constituency. As would appear from the frequency of the use of the Protocol on Subsidiarity and the involvement of national parliaments mechanism instituted thereby, the national parliaments are not really able or willing to make use of it.

As for the Data Retention Directive itself, it can hardly be suggested that there was no debate about the measure prior to its adoption: the measure itself was first tabled in 2000, rejected and re-worked several times, but in the end adopted in the aftermath of the 2005 London bombings. ${ }^{109}$ The eventual adoption of the Directive could thus be seen not necessarily as an example of the absence of deliberation prior to its adoption, but rather an example of the dangerous impact of one exceptional situation and the (over-)use of emergency rhetoric eventually pushing through a highly problematic measure.

2.12.3 The fact that a Member State has 'suddenly' awakened to find that a measure previously adopted on the EU level happens to be incompatible with its national constitutional rules should not constitute a sufficient ground for suspending/ circumventing the execution of its obligation.

However, two measures should be contemplated instead. First, a Member State that believes that an adopted EU measure is incompatible with its constitutional order should be obliged to bring, within the appropriate period, an annulment action before the Court of Justice. Secondly, if it fails to do so, if the problem is only detected later at the stage of the national application of the measure, the national

\footnotetext{
106 Case C-399/09 Landtová [2011] ECR I-05573.

107 Judgment in Holubec, n. 29 above.

108 In detail Bobek 2014, pp. 78-84.

${ }^{109}$ In detail see Jones and Hayes 2013, pp. 6-11.
} 
court addressing the issue should submit a request for a preliminary ruling on validity to the Court of Justice, which is in fact already the requirement following Melki and Abdeli. ${ }^{110}$ Both of these avenues, taken conjointly or separately, would allow the Court of Justice to be seized with the issue and for the concern of the Member State and other actors to be heard. At the same time, the fact that such an action concerning the validity of a measure was pending before the Court of Justice, irrespective of whether it had been brought as a direct action by the Member State or as a request for a preliminary ruling, would be a sufficient reason for the Court of Justice to suspend the Art. 258 TFEU procedure before the question on validity is decided on merits. However, failure to bring an action before the Court of Justice, a 'defence' in the framework of Art. 258 TFEU, would not be sufficient in itself.

\subsection{Experts' Analysis on the Protection of Constitutional Rights in EU Law}

2.13.1 We do not share entirely the editors' concerns about an overall reduction in the standard of protection of constitutional rights in EU law. The 'reduction of protection' suggestion might be true if viewed through the lenses of the level of protection that was extant before 2004 in some of the new Member States. When viewed diachronically within the EU legal order itself, however, i.e. comparing the level of fundamental rights protection in the EU in the past and today, the same suggestion becomes much more questionable.

We are far from suggesting that 'all is well' with regard to the fundamental rights protection in EU law. To talk of an 'overall reduction' on an EU-wide level (i.e. not just contrasted with the rather abnormal, transformative situation in the new Member States before 2004) would, however, appear to be far-fetched. In addition, the signs coming from the Luxembourg courts since 2009 and the entry into force of the Charter appear to hint at a movement in the other direction: the amount of annulments of EU legislation has increased. This number may not be dramatic, but since previously it was close to zero, any increase counts.

2.13.2 Even though the answer to the previous question was 'no', as a general rule of thumb, it may be only suggested that the way forward for the EU protection of fundamental rights is certainly not in the creation of new institutions, new tribunals or new, complex procedures, including the EU accession to the ECHR. In general, creating new institutions or procedures rather shifts the original responsibility to someone else without reforming the original problem. Moreover, after Opinion 2/ $13,{ }^{111}$ it is unlikely that the EU accession will happen any time soon.

${ }^{110}$ Joined cases C-188/10 and C-189/10 Melki and Abdeli, n. 33, paras. 54-55.

${ }^{111}$ Opinion 2/13 Opinion pursuant to Art. 218(11) TFEU [2014] ECLI:EU:C:2014:2454. 
However, the fact that the Court of Justice will in the foreseeable future not be subject to external scrutiny from Strasbourg means that it should be obliged to take fundamental rights protection within the EU legal order into its own hands and provide it with even greater post-Lisbon vigour, in particular with regards to acts of the EU institutions themselves. Moreover, the absence of accession to the procedural framework in no way means the absence of being bound by the substance of Strasbourg case law. Already today, Art. 52(3) of the Charter connects the Court of Justice internally to the ECHR and the case law of the Strasbourg Court. This provision ought to be taken seriously, applied faithfully and visibly adhered to not only in the Opinions of the Advocates General, but also in the reasoning of the Court of Justice.

2.13.3 In contrast to the academic calls of Anglo-American provenance, one of the authors of this report has repetitively expressed his doubts as to how far the current reasoning style of the Court of Justice can be still called 'cryptic and Cartesian'. ${ }^{112}$ If measured against the English or American judicial style, the reasoning of the Court of Justice might indeed appear to be rather condensed. The style may be viewed with much greater understanding if measured against the Germanic Continental tradition, and it might be judged as outright lengthy and too discursive if compared with the Latin Continental tradition. On the other hand, sharing more information on the Court's judicial business, as well as background information, could only be welcome. Equally, everyone is bound to agree that greater responsiveness to the parties would be also appreciated, of course within the limits of the possible, taking into account the length of the decisions and the need for their translation into all the other languages of the Union.

\section{Constitutional Issues in Global Governance}

\subsection{Constitutional Rules on International Organisations and the Ratification of Treaties}

3.1.1 Since the 2001 EU Amendment discussed in detail in Sect. 1.2.1 above, the Slovak Constitution governs the transfer of powers to international organisations predominantly in its Art. 7 (see Sect. 1.2.1 for the full wording). The different sub-sections of Art. 7 have different purposes.

Article 7(1) addresses the possibility of a radical change in the constitutional design, namely an entry into a 'state union' with other states (or withdrawal from such a union). This provision allows the SR to join a federation, requiring the adoption of a constitutional law and a referendum.

Article 7(2) allows for accession to the EU, as has been discussed above.

${ }^{112}$ Further Bobek 2013b, pp. 203-208; or Bobek 2015, pp. 169-172. 
Article 7(3) is another specific provision that was adopted in order to allow for the accession of the SR to NATO. This provision is different from Art. 7(2) in that it explicitly refers to the objectives sought by accession, namely 'maintaining peace, security and democratic order'. Article 7(3) does not refer directly to NATO, but allows accession of the SR to 'an organization of mutual collective security'. ${ }^{113}$

Articles 7(4) and 7(5) determine the applicability of international treaties and their position in the hierarchy of the Slovak legal order.

Interestingly enough, the provisions of Art. 7 do not contain any limits to the delegation of powers to international or supranational organisations (the only limit being that the SR may only transfer the exercise of a part of its rights; see Sect. 1.3.3 above for more detail), nor any values or principles that ought to be upheld by the SR when participating in international co-operation. It remains to be seen whether such limits or values will be developed in the case law of the SCC. This could happen either in the framework of fundamental rights protection (where the SCC has consistently held that the standard of protection cannot be weakened) or on the occasion of ex ante review of any future international treaty, pursuant to Art. 125a (which has not yet been used).

As for the ratification process itself, the relevant provisions are Arts. 84 and 86 (dealing with the NCSR), Art. 102(a) (concerning the powers of the President) and Art. 119(f) (relating to the Government). Pursuant to Art. 86(d), the power of the NCSR comprises (inter alia)

expressing consent, prior to ratification, to international treaties on human rights and fundamental freedoms, international political treaties, international treaties of military nature, international treaties establishing membership of the SR in international organizations, international economic treaties of a general nature, international treaties whose execution requires the enactment of a law, as well as with international treaties that directly establish rights or obligations of natural persons or legal persons, and at the same time determining if these are international treaties stipulated in Art. 7(5).

Pursuant to Art. 102(1)(a), the President 'represents the SR outwardly and concludes and ratifies international treaties. He may delegate to the Government of the SR or, with the Government's consent, to individual members of the Government of the SR, the conclusion of international treaties'. Finally, pursuant to Art. 119(f), the Government decides on 'international treaties of the SR, the negotiation of which has been transferred by the President of the SR to the Government'.

${ }^{113}$ See Drgonec 2012. Drgonec has argued that the singular form used in Art. 7(3) precludes the possibility to enter into more than just one such organisation, and that the purpose of this subsection has been exhausted by the accession of the SR to NATO. However, the authors believe that this is a rather unpersuasive argument, especially since Drgonec seems to be inconsistent in his approach to textual interpretation: while in his commentary to Art. 7(3) he puts substantial weight on the singular/plural wording of the article, in his commentary to Art. 7(1) he argues that the plural form ('with other states') has to be read so as to also include situations where the SR enters into a 'state union' with just one other state. 
The Constitution does not differentiate between international treaties negotiated by the SR and international treaties to which the SR accedes subsequently, without having a say in the negotiation process (such as the NATO Treaty, concluded long before the SR acceded). ${ }^{114}$ The objective of ratification by the NCSR is therefore rather limited - the legislator does not influence the content of the treaty (this task remains with the executive branch), but rather confirms the will of the SR to be bound by the given international obligations. ${ }^{115}$

3.1.2 As already discussed in detail in Sects. 1.2 and 1.3 above, the present form of Art. 7 and the various sub-categories of international organisation to which the SR may potentially accede is the result of the 2001 EU Amendment of the Slovak Constitution. According to the position of the NCSR, the adoption of Art. 7(1) was 'a result of a generally known fact that state unions have been unpredictably and unregularly formed and dissolved in history ${ }^{116}$ and the aim of this provision was 'to create a legal basis for future changes, not foreseen at the time when the Constitution was adopted, which lead to the SR entering a state union with another state or states'. 117

As for the wording of Art. 7(2), one of the contemplated versions of its wording was that the SR may 'transfer a part of the exercise of its sovereignty,' but this draft wording was later changed to 'rights'. Azud has argued that the reference to 'sovereignty' was more appropriate, and that Art. 7(2) should not only refer to the EC/EU, but rather to 'supranational bodies' in general. ${ }^{118}$

3.1.3 To our knowledge, there has not been any discussion about the need to amend the wording of any of the articles concerning international obligations and effects of international and supranational law.

\subsection{The Position of International Law in National Law}

3.2.1 Prior to the EU Amendment (2001), the only provision relevant to the place of international treaties in the Slovak legal order was Art. 11 (now repealed): 'International treaties on human rights and fundamental freedoms, which have been ratified and promulgated in a manner laid down by law, shall have primacy over the

\footnotetext{
114 Drgonec 2012, p. 120.

115 Ibid., pp. 120-121.

116 See the parties' argumentation in Judgment of the SCC, II. ÚS 171/05 (EU Constitutional Treaty) of 27 February 2008. The submission then goes on to name several examples of such 'state unions', e.g. the Kalmar Union (1397-1523), the Polish-Lithuanian Union (1569-1795), French West Africa (1904-1958), the Soviet Union (1922-1991), the Socialist Federal Republic of Yugoslavia (1945-1992), the Union of African States (1960-1962) and, most importantly, the Czechoslovak Federation (1918-1992).

117 Ibid., p. 122.

118 Azud 2003, p. 596.
} 
laws of the Slovak Republic, if they guarantee a greater scope of constitutional rights and freedoms. ${ }^{, 19}$ This was the only provision governing the relationship between international law and domestic law, and it only covered those treaties that guaranteed 'a greater scope of constitutional rights' than the Slovak Constitution. ${ }^{120}$ Academic writers have named this concept 'the principle of alternative primacy of international law' or 'the conditional primacy of international treaties'. ${ }^{121}$

The SCC had an opportunity to cast more light on the interpretation of Art. 11 in December 1999 when deciding on a constitutional complaint launched by a Belarusian citizen (Mr. A.R.) who had been criminally prosecuted in the SR and who claimed that his rights under Art. 6 of the ECHR and under Art. 4 of Protocol 7 to the ECHR had been violated by the Regional Court in Košice. The claimant did not invoke any of the provisions of the Slovak Constitution, and the SCC therefore had to clarify whether it was competent to hear a constitutional complaint that only raised points under provisions of an international human rights treaty. ${ }^{122}$

The SCC opened its (very brief) reasoning by asserting that the Constitution did not offer an unambiguous solution to the problem of the relationship between international human rights treaties and the domestic legal order. It then proceeded to argue that the problem could be resolved with the help of Art. 11 of the Constitution and Act No. 1/1993 Coll., on the Collection of Laws of the SR, according to which international treaties form part of the legal order of the SR when certain conditions are satisfied (which they were, in the case of the ECHR). The SCC further stated that it is competent to decide constitutional complaints brought by natural or legal persons who claim a violation of their rights (Art. 130(3) of the Constitution), and that the rights allegedly violated must be duly characterised and identified, as required by law. ${ }^{123}$ According to the SCC, this legal provision requires a due characterisation and identification of not just any right, but a particular right guaranteed by the Slovak Constitution. To support this argument, the SCC referred to some academic works, and then concluded:

International human rights treaties have a special place in the hierarchy of legal sources in the SR. Upon fulfilment of the conditions stipulated in Art. 11 of the Constitution, they have primacy over the laws of the SR. Although they have primacy over (ordinary) laws, they do not have primacy over the Constitution. They cannot be considered to be part of constitutional law. The protection of rights and freedoms therein embedded thus does not amount to a protection of constitutionality. The Constitutional Court is an institution protecting constitutionality. Therefore, the Constitutional Court is not competent to deal with the protection of rights and freedoms embedded in international instruments, if the

\footnotetext{
119 This construction dates in fact back to the times of the Czechoslovak Federation. Further see Bobek and Kosař 2010.

${ }^{120}$ This formulation has created some uncertainty: how exactly is it to be determined which source of law guarantees 'a greater scope of protection'? See for example Balog 2009, p. 2.

${ }^{121}$ Klučka 1993, p. 295. See also Balog 2009, pp. 2-3.

122 Judgment of the SCC, II. ÚS 91/99 (Belarusian citizen) of 16 December 1999.

${ }^{123}$ Act No. 38/1993 Coll., on the organization of the Constitutional Court of the Slovak Republic;
} $\S 20$. 
claimant does not at the same time claim a violation of a right or freedom that is guaranteed by the Slovak Constitution. ${ }^{124}$

The SCC dismissed the constitutional complaint. By this decision, the SCC clearly identified the position of international human rights treaties in the hierarchy of legal norms: they stand above ordinary laws, but below the norms of constitutional legal force.

When Art. 11 was repealed in 2001, its content was relocated to Art. 7(5) and Art. 154c of the Constitution. Article 7(5) now establishes the primacy of three types of international treaties: (1) treaties on human rights and fundamental freedoms; (2) self-executing treaties; and (3) treaties with direct effect; on condition that they have been 'ratified and promulgated in a manner laid down by law'. It follows from Art. 86(d) in fine of the Constitution that it is up to the NCSR to decide whether an international treaty falls into one of these three categories.

As for international treaties that were ratified and promulgated before 1 July 2001 (i.e. before the EU Amendment entered into force), these are governed by Art. $154 \mathrm{c}$ of the Constitution, pursuant to which they form part of the Slovak legal order and they have primacy over (ordinary) laws on condition that they provide either (a) 'a greater scope of constitutional rights and freedoms' (para. 1), such as the ECHR, or (b) 'if so laid down by law' (para. 2), such as the United Nations Convention on Contracts for the International Sale of Goods (No. 160/1991 Coll.).

To take the example of the ECHR, this international treaty has a very special place in the system of human rights protection in Slovakia, which has also been consistently recognised by the SCC in its case law. In one of its most recent cases, the SCC has held that 'the fundamental rights and freedoms embedded in the Constitution are to be interpreted and applied in the sense and in the spirit of international treaties on human rights and fundamental freedoms and the relevant case law that interprets them'. ${ }^{125}$ This principle follows from the legal effect of the ECHR, as well as from the principle of pacta sunt servanda. ${ }^{126}$

3.2.2 The original version of the Slovak Constitution adopted in 1992 was predominantly dualist, with no general incorporation clause for provisions of international law (see Sect. 3.2.1 above). The only monist element in the original Constitution was the conditional inclusion of some international treaties. The EU Amendment of 2001 made a significant change to the constitutional architecture and brought the Slovak legal order much closer to monism. ${ }^{127}$

\footnotetext{
${ }^{124}$ Judgment of the SCC, II. ÚS 91/99, n. 123, translation by the authors; see also the comment by Drgonec 2013.

125 Judgment of the SCC, Pl. ÚS 10/14 (Data retention), n. 14, para. 84, which refers to a well-established line of case law in which the Court has ruled the same. Translation by the authors. ${ }^{126}$ See e.g. Judgment of the SCC, I. ÚS 5/02 (Publicity of judgments) of 21 May 2003.

${ }^{127}$ For a more detailed analysis of the monist nature of the Slovak legal order, see Dobrovičová 2007 , pp. 55 et seq.
} 


\subsection{Democratic Control}

3.3.1 The Parliament's involvement in the initial negotiations of international treaties is close to none, since the negotiations belong to the competences of the executive, rather than the legislative branch. Even the possibility of ex ante review of international treaties (see Sect. 3.4 below) excludes the NCSR from initiating the review procedure, since only the President of the Republic and the Government have standing. The NCSR thus remains uninvolved in the negotiations, and its role is limited merely to give consent to ratification, pursuant to Art. 86(d) of the Constitution.

On the other hand, it ought to be added that should the NCSR so wish, it may obtain information and may subject the Government to parliamentary scrutiny via the normal channels of governmental responsibility, such as requesting information as to the status of negotiations or ratification from the relevant minister, subjecting the responsible minister or Prime Minister to questioning on these issues during parliament question time, requesting a committee to address the issues, etc. The pragmatic reasons for these mechanisms not being activated too frequently are twofold: first, as in any form of parliamentary democracy, it is in practical terms rather the Government that controls the Parliament and not always vice-versa, and, secondly, international and/or European affairs tend in general not to be in the limelight of parliamentary interest.

3.3.2 The only valid referendum in the history of the SR has been the 2003 referendum on the Slovak accession to the European Union (see Sect. 1.4.2).

In May 1997, the SR held a referendum on a number of issues related to national defence. The first out of four questions was phrased 'Do you agree with the accession of the SR to NATO?' This referendum, however, had the lowest turnout $(9.53 \%)$ in history, and was therefore not valid. ${ }^{128}$

\subsection{Judicial Review}

3.4.1 The judicial review of provisions of international law is limited in the SR to the ex ante review of international treaties pursuant to Art. 125a of the Constitution, the text of which was provided in Sect. 1.2. This provision was introduced into the Slovak legal system by the EU Amendment in 2001, but has not yet been used, most likely because only the President and the Government have standing to bring such a claim.

${ }^{128}$ See the webpage of the Slovak Statistical Office at http://slovak.statistics.sk/. 


\subsection{The Social Welfare Dimension of the Constitution}

3.5.1-3.5.2 Not applicable to the Slovak report, since Slovakia has never been subject to any bail-out programme.

\subsection{Constitutional Rights and Values in Selected Areas of Global Governance}

3.6.1 No significant further issues have arisen.

\section{References}

Azud J. (2003) K otázke vplyvu vstupu SR do EÚ na suverenitu SR v kontexte čl. 7 Ústavy Slovenskej republiky (On the Influence of the Slovak Accession to the EU on the Sovereignty of the SR in the Context of Art. 7 of the Slovak Constitution). Právny obzor 86(6):591-609.

Balog B. (2009) International Treaties in the Constitutional System of the Slovak Republic. In: Conference Proceedings from the International Conference Days of Law, Masaryk University, Brno, 18-19 November 2009. https://www.law.muni.cz/sborniky/dny_prava_2009/files/ mezin_smlouvy.html.

Bartovič V. (2010) National Council of the Slovak Republic in the EU Agenda: Giant in Theory, Dwarf in Practice. In: Král D., Bartovič V. (eds.) The Czech and the Slovak Parliaments after the Lisbon Treaty. Europeum, Prague, pp. 47-78.

Besselink L. (2006) The Dutch Constitution, the European Constitution and the Referendum in the Netherlands. In: Albi A., Ziller J. (eds.) The European Constitution and National Constitutions: Ratification and Beyond. Kluwer Law International, Alphen aan den Rijn, pp. 113-123.

Bobek M. (2006-2007) The Binding Force of Babel: The Enforcement of EC Law Unpublished in the Languages of the New Member States. Cambridge Yearbook of European Legal Studies 9:43-80.

Bobek M. (2013a) Comparative Reasoning in European Supreme Courts. Oxford University Press, Oxford.

Bobek M. (2013b) Of Feasibility and Silent Elephants: The Legitimacy of the Court of Justice through the Eyes of National Courts. In Adams M. et al (eds.) Judging Europe's Judges: the Legitimacy of the Case Law of the European Court of Justice. Hart Publishing, Oxford, pp. 197-234.

Bobek M. (2014) Landtová, Holubec, and the Problem of an Uncooperative Court: Implications for the Preliminary Rulings Procedure. EuConst 10:54-89.

Bobek M. (2015) The Court of Justice of the European Union. In: Arnull A., Chalmers D. (eds.) The Oxford Handbook of EU Law. Oxford University Press, Oxford, pp. 153-177.

Bobek M. (2016) The Court of Justice, the National Courts, and the Spirit of Cooperation: Between Dichtung und Warheit. In Lazowski A., Blockmans S. (eds.) Research Handbook on EU Institutional Law. Edward Elgar, Cheltenham, pp. 353-373.

Bobek M. (2017) Fundamental Rights and Fundamental Values in the Old and the New Europe. In Douglas-Scott S., Hatzis N. (eds.) Edward Elgar Research Handbook on EU Human Rights Law. Edward Elgar, Cheltenham, pp. 309-323.

Bobek M., Kosař D. (2010) The Application of European Union Law and the Law of the ECHR in the Czech Republic and Slovakia: An Overview. In: Martinico G., Pollicino O. (eds.) National 
Judges and Supranational Laws: A Comparative Overview of the National Treatment of EU Law and the ECHR. Europa Law Publishing, Groningen, pp. 157-190.

Bröstl A. (2013) Ústavné právo Slovenskej republiky (Constitutional Law of the Slovak Republic). Aleš Čeněk, Plzeň.

De Witte B. (2012) The European Union as an International Legal Experiment. In: De Búrca G., Weiler J.H.H. (eds.) The Worlds of European Constitutionalism. Cambridge University Press, Cambridge, pp. 19-56.

Dobrovičová G. (ed.) (2007) Vplyv medzinárodného práva a európskeho práva na právny poriadok Slovenskej republiky (The influence of international law and European law on the legal order of the Slovak Republic). UPJŠ, Košice, pp. 55-69.

Drgonec J. (2010) Ochrana ústavnosti Ústavným súdom Slovenskej republiky (Protection of Constitutionality by the Slovak Constitutional Court). Eurokódex, Žilina.

Drgonec J. (2012) Ústava Slovenskej republiky: Komentár (The Constitution of the Slovak Republic: A Commentary). Heuréka, Šamorín.

Drgonec J. (2013) Ústavné a úniové právo: začneme hladat' rozumnú rovnováhu? (Constitutional Law and Union Law: shall we start looking for a reasonable balance?) Justičná Revue 11:1463-1489.

Freedland M., Prassl J. (eds.) (2014) EU Law in the Member States: Viking, Laval and Beyond. Hart Publishing, Oxford.

Hodás M. (2008) Kumulatívna citácia publikačného zdroja právnych aktov ES/EÚ v multilinguálnom prostredí Európskej únie (Cumulative Citation of Publication Source of EC/EU Legal Acts in the Multilingual Setting of the EU). Právny obzor 91, pp. 6 et seq.

Hodás M. (2011) Komparatívny ústavnoprávny pohl’ad na inštitút európskeho zatýkacieho rozkazu a nedostatky slovenskej ústavnej úpravy (Comparative Constitutional Assessment of the European Arrest Warrant and the Shortcomings of the Slovak Constitutional Solution). Acta Iuridica Olomucensia 6:2 et seq.

Jakubčík S. (2009) Európsky zatýkací rozkaz a problémy jeho aplikácie v praxi (The European Arrest Warrant and Some Practical Problems with its Application). Justičná revue 10:61 et seq.

Jánošíková M. (2014) Ústava Slovenskej republiky a členstvo Slovenskej republiky v Európskej únii (The Slovak Constitution and the Membership of the Slovak Republic in the European Union). Iuridicum Univerzita Karlova No. 4/2013.

Jones C., Hayes, B. (2013) The EU Data Retention Directive: a case study in the legitimacy and effectiveness of EU counter-terrorism policy. SECILE project paper. http://www.statewatch. org/news/2013/dec/secile-data-retention-directive-in-europe-a-case-study.pdf.

Kiikeri M. (2001) Comparative Legal Reasoning and European Law. Springer, The Hague.

Klučka J. (1993) Medzinárodné právo a právny poriadok Slovenskej republiky (International Law and the Legal Order of the Slovak Republic). Právny obzor 76:4 et seq.

Komárek J. (2007) European Constitutionalism and the European Arrest Warrant: In Search of the Limits of 'Contrapunctual Principles'. CML Rev. 44:9-40.

Komárek J. (2009) The Czech Constitutional Court's Second Decision on the Lisbon Treaty of 3 November 2009. EuConst 5:345-352.

Lenaerts K. (2003) Interlocking Legal Orders in the European Union and Comparative Law. ICLQ 52:873-906.

Přibáñ J. (2015) Constitutional Sovereignty in Post-Sovereign Jurisprudence of the Czech Constitutional Court. In: Bobek M. (ed.) Central European Judges Under the European Influence: The Transformative Power of the EU Revisited. Hart Publishing, Oxford, pp. 180 199.

Procházka R. (2002) Mission Accomplished: On Founding Constitutional Adjudication in Central Europe. CEU Press, Budapest.

Procházka R. (2004) K publicite prameňov komunitárneho práva (On the Publicity of Sources of Community Law). Justičná revue 56:8-9.

Siegel S. (2008) Courts and Compliance in the European Union: The European Arrest Warrant in National Constitutional Courts. Jean Monnet Working Paper No. 05/08. http://www. jeanmonnetprogram.org/papers/08/080501.pdf. 
Stein E. (1997) Out of the Ashes of a Federation, Two New Constitutions. Am.J.Comp.L. 1997:45-69.

Walker N. (2012) The Place of European Law. In: De Búrca G., Weiler J.H.H. (eds.) The Worlds of European Constitutionalism. Cambridge University Press, Cambridge.

Zbíral R. (2012) Czech Constitutional Court, Judgment of 31 January 2012, Pl. ÚS 5/12: A Legal Revolution or Negligible Episode? Court of Justice Decision Proclaimed Ultra Vires. CML Rev. 49:1-18.

Zweigert K. (1949) Rechtsvergleichung als universale Interpretationsmethode. Zeitschrift für Ausländisches und Internationales Privatrecht (later RabelsZ) 15:5 et seq.

Open Access This chapter is licensed under the terms of the Creative Commons Attribution 4.0 International License (http://creativecommons.org/licenses/by/4.0/), which permits use, sharing, adaptation, distribution and reproduction in any medium or format, as long as you give appropriate credit to the original author(s) and the source, provide a link to the Creative Commons license and indicate if changes were made.

The images or other third party material in this chapter are included in the chapter's Creative Commons license, unless indicated otherwise in a credit line to the material. If material is not included in the chapter's Creative Commons license and your intended use is not permitted by statutory regulation or exceeds the permitted use, you will need to obtain permission directly from the copyright holder. 